INTER NATIONAL MONETARY FUND

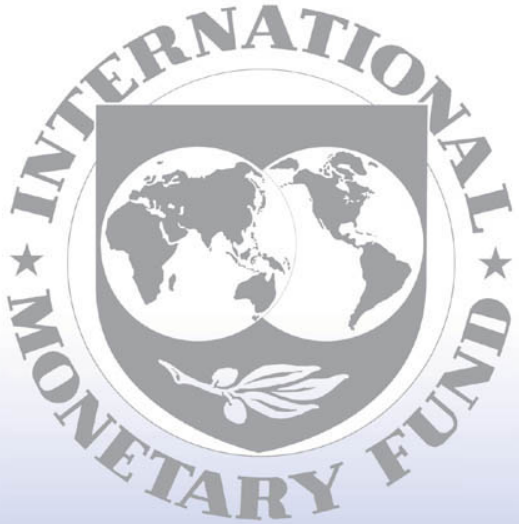

Staff

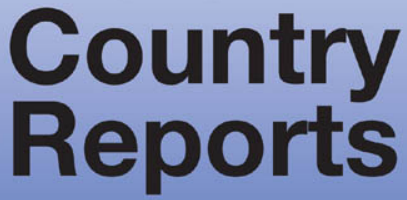




\section{Thailand: Financial Sector Assessment Program-Technical Note- Fixed Income Markets}

This technical note on fixed income markets for Thailand was prepared by a staff team of the International Monetary Fund as background documentation to the Financial Sector Assessment Program with the member country. It is based on the information available at the time it was completed in April 2008. The views expressed in this document are those of the staff team and do not necessarily reflect the views of the government of Thailand or the Executive Board of the IMF.

The policy of publication of staff reports and other documents by the IMF allows for the deletion of market-sensitive information.

Copies of this report are available to the public from

International Monetary Fund $\bullet$ Publication Services

700 19th Street, N.W. • Washington, D.C. 20431

Telephone: (202) 623-7430 • Telefax: (202) 623-7201

E-mail: publications@imf.org • Internet: http://www.imf.org

\section{International Monetary Fund Washington, D.C.}


This page intentionally left blank

CInternational Monetary Fund. Not for Redistribution 


\title{
FinANCial SEctor Assessment Program
}

\section{THAILAND}

\author{
TECHNICAL NOTE
}

FiXed INCOME MARKETS

APRIL 2008

INTERNATIONAL MONETARY FUND MONETARY AND CAPITAL MARKETS DEPARTMENT
THE WORLD BANK FINANCIAL AND PRIVATE SECTOR DEVELOPMENT VICE PRESIDENCY EAST ASIA AND PACIFIC REGION VICE PRESIDENCY 


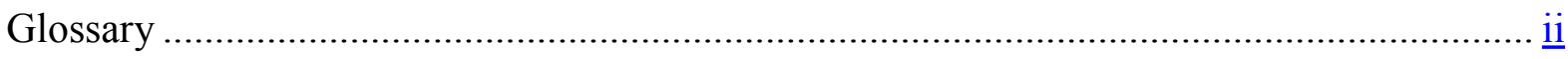

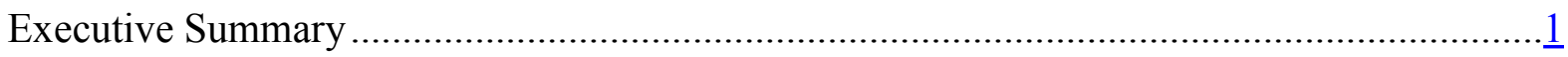

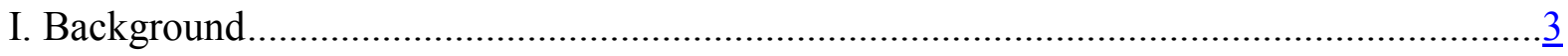

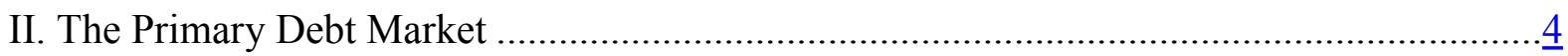

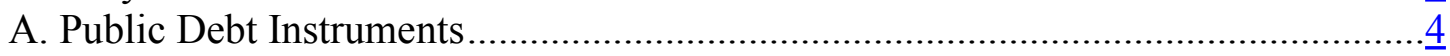

B. Primary Market for Public Debt.........................................................................

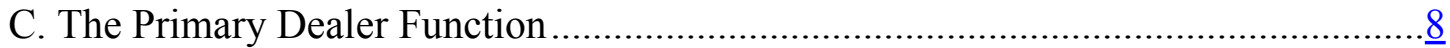

D. Primary Market for Corporate Debt..............................................................12

E. Primary Market Factors Affecting Secondary Market Activity ...............................

F. Other Related Fixed Income Markets..................................................................16

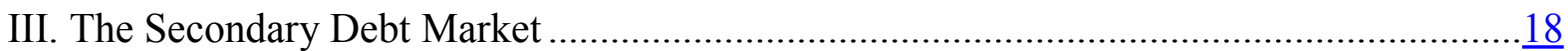

A. Secondary Market Activity ……………………….........................................

B. Secondary Market Infrastructure...............................................................

C. Secondary Market Intermediaries ……………………...................................

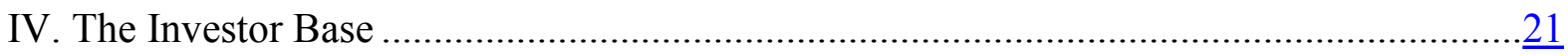

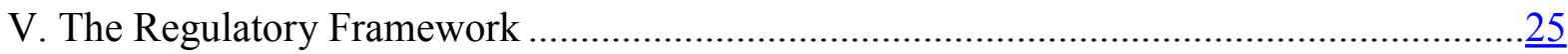

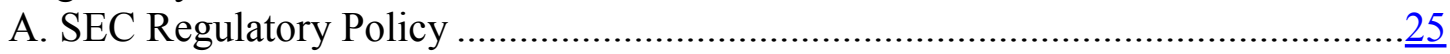

B. Initiative to Promote Securitization...................................................................26

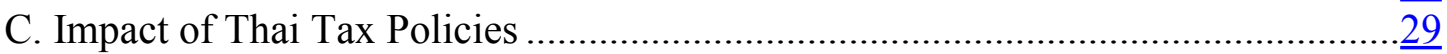

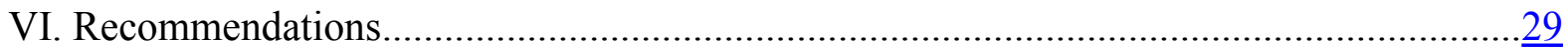

A. The Government Debt Market ......................................................................

B. Recommendations on Corporate Debt Market.....................................................

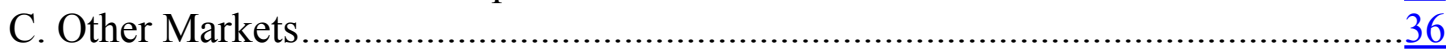

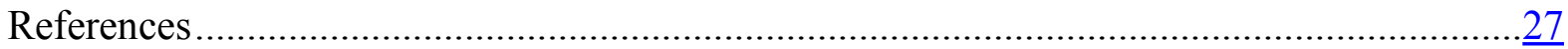

Tables

1. Regional Bond Market Indicators, End-2006 ...............................................................

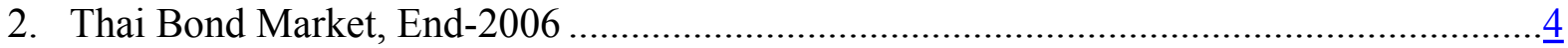

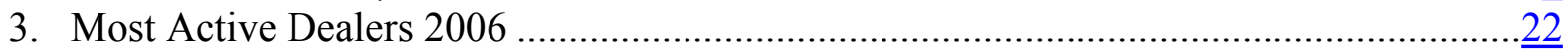

4. Development of the Mutual Fund Industry.................................................................

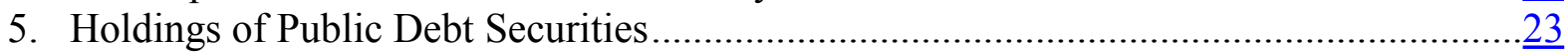

Figures

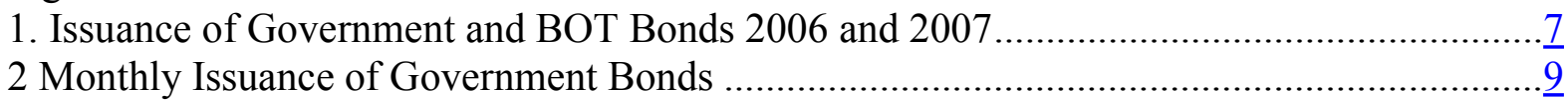

3. Indicators of Liquidity in East Asian Bond Markets ………............................................ $\frac{19}{28}$

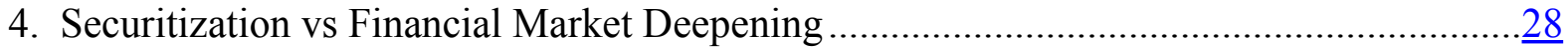

Box

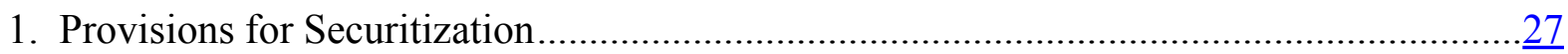




\section{GLOSSARY}

$\begin{array}{ll}\text { ADB } & \text { Asian Development Bank } \\ \text { BEX } & \text { Bond Electronic Exchange } \\ \text { BOT } & \text { Bank of Thailand } \\ \text { FIDF } & \text { Financial Institutions Development Fund } \\ \text { FIRSTS } & \text { Fixed Income and Related Trading System } \\ \text { FX } & \text { Foreign Exchange } \\ \text { GHB } & \text { Government Housing Bank } \\ \text { GMRA } & \text { Global Mater Repurchase Agreement } \\ \text { GSB } & \text { Government Savings Bond } \\ \text { IRS } & \text { Interest Rate Swaps } \\ \text { JBIC } & \text { Japan Bank for International Cooperation } \\ \text { MOF } & \text { Ministry of Finance } \\ \text { NAV } & \text { Net Asset Value } \\ \text { OTC } & \text { Over-the-Counter } \\ \text { PDA } & \text { Public Debt Act } \\ \text { PD } & \text { Primary Dealer } \\ \text { PDMO } & \text { Public Debt Management Office } \\ \text { RFQ } & \text { Request for Quotes } \\ \text { SBT } & \text { Specific Business Tax } \\ \text { SEC } & \text { Securities and Exchange Commission } \\ \text { SET } & \text { Stock Exchange of Thailand } \\ \text { SOE } & \text { State Owned Enterprise } \\ \text { SPAf } & \text { Security Position Adjustment Facility } \\ \text { SRO } & \text { Self-Regulatory Organizations } \\ \text { Tbill } & \text { Treasury bill } \\ \text { TBMA } & \text { Thai Bond Market Association } \\ \text { TFEX } & \text { Thai Futures Exchange } \\ \text { TSD } & \text { Thailand Securities Depository CO., Ltd. }\end{array}$




\section{EXECUTIVE SUMMARY}

The debt market in Thailand has made important strides since the financial crisis of 1997. The Thai government has made significant progress in building an orderly yield curve and is beginning to establish some benchmarks. However, more needs to be done if the government is to achieve its objective of enhancing liquidity in the market. In particular, liquidity in the secondary market would be enhanced by reducing the frequency of auctions, while increasing the size of each individual offering. Such a change will require primary dealers to change their mode of operation from effectively a "broking" operation to the provision of greater underwriting and market making services; consequently a review of the primary dealer system is warranted. Nevertheless, prospects for development of the government securities market will be constrained overall by the likely limited financing need going forward, unless the authorities can secure some additional flexibility to restructure the existing portfolio or otherwise establish more meaningful benchmarks.

The corporate debt market suffers from too few issuers of corporate debt and too little diversity of debt offerings. This reflects, in part the limited corporate need for long-term financing, the ready availability of alternative financing by commercial banks at competitive rates, and regulatory policies that emphasize investor protection by imposing substantial limitations on the ability of institutional investors to purchase anything but investment grade debt, which effectively precludes issuance of below investment grade debt.

Thailand should begin an orderly transition from merit-based regulation of corporate issuers and institutional investors to a disclosure-based regulatory system that opens the debt market to a larger and more diverse pool of corporations and allows institutional investors with the freedom to make their own decisions on what investments to make, based upon informed assessments of risk and return, provided that these decisions are fully disclosed to investors.

A series of regulatory changes should be considered including removing the limitations on below investment grade debt offerings, expanding the size of private placement offerings and reducing the regulatory burdens on issuers of short-term commercial paper. Comparable regulatory relief for investors should be considered such as permitting the creation of mutual funds that invest in high yield securities, reconsidering the definition of an illiquid security and/or reducing the restrictions on the investment in illiquid securities, permitting institutions greater flexibility in engaging in hedging strategies, permitting institutions to invest in offshore offerings and allowing institutions to resell private placement securities in the secondary market.

Greater liquidity in the secondary debt market can best be achieved by increasing the supply of debt issues and providing institutions with greater freedom to buy and sell. The secondary debt market would also benefit if long-standing limitations on the number of securities firms 
were discarded in order to promote greater competition among financial services intermediaries.

In addition, the ability of financial intermediaries to become more active liquidity providers in the secondary market would be enhanced by the provision of more appropriate derivatives products to hedge interest rate risk. Moving forward with introducing the anticipated futures contract on TFEX will be a significant step in meeting that need. 


\section{FIXED INCOME MARKETS IN THAILAND ${ }^{1}$}

1. This note reviews the functioning of the fixed income markets, particularly the bond markets, in Thailand. Section I provides some brief background; Section II discusses the primary markets for public sector and corporate debt instruments; Section III discusses the functioning of the secondary bond markets; Section IV the investor base; while section V discusses the regulatory framework. Finally, Section VI summarizes the key recommendations and concludes.

\section{BACKGROUND}

2. Table 1 outlines some key facts about the bond markets in Thailand relative to other countries in the region. Within this sample, Thailand is the fourth largest market; however, as indicated by its relative turnover ratio, ${ }^{2}$ it is one of the most illiquid.

Table 1. Thailand: Regional Bond Market Indicators, End-2006

\begin{tabular}{|c|c|c|c|c|c|c|c|c|c|}
\hline & \multicolumn{3}{|c|}{$\%$ of GDP } & \multicolumn{3}{|c|}{ In USD billions } & \multicolumn{3}{|c|}{ Turnover ratio } \\
\hline & Govt & Corp & Total & Govt & Corp & Total & Govt & Corp & Total \\
\hline Thailand* & 38 & 19 & 58 & 75 & 37 & 112 & 1.3 & 0.1 & 1.1 \\
\hline China & 31 & 16 & 46 & 786 & 398 & 1,184 & 1.4 & 0.8 & 1.2 \\
\hline Hong Kong & 9 & 42 & 51 & 17 & 79 & 96 & 68.2 & 0.2 & 12.1 \\
\hline Indonesia & 13 & 2 & 15 & 47 & 7 & 53 & 0.8 & 0.3 & 0.8 \\
\hline Korea** $^{* *}$ & 54 & 56 & 109 & 469 & 90 & 959 & 2.6 & 0.5 & 1.6 \\
\hline Malaysia & 41 & 41 & 83 & 61 & 60 & 121 & 1.9 & 0.6 & 1.3 \\
\hline Philippines & 37 & & 37 & 44 & & 44 & & & \\
\hline Singapore & 42 & 32 & 74 & 56 & 43 & 99 & 2.5 & - & 1.4 \\
\hline Vietnam & 8 & 1 & 9 & 5 & 0 & 5 & & & \\
\hline
\end{tabular}

Source: Asian Bonds Online.

* The total for corporate debt securities also includes bonds issued by state owned enterprises.

** Data on turnover ratio is for Dec-2005.

3. In terms of the overall composition of the bond market, public debt securities account for most of the bonds, with the residual comprising corporate bonds. Bonds issued by foreign issuers are insignificant (Table 2). In terms of secondary market activity, Treasury bills are by far the most liquid debt security, followed by Bank of Thailand (BOT) bills and BOT bonds, which are also relatively short-term.

\footnotetext{
${ }^{1}$ Prepared by Allison Holland, IMF and Jonathan Katz, World Bank consultant.

${ }^{2}$ Note turnover of Treasury bills has been included in the total turnover ratio for Government bonds for Thailand.
} 
Table 2. Thailand: Thai Bond Market, End-2006

\begin{tabular}{|c|c|c|c|c|}
\hline & $\begin{array}{c}\text { Amount } \\
\text { outstanding } \\
\text { (bn) }\end{array}$ & $\begin{array}{c}\text { \% of Total } \\
\text { Market }\end{array}$ & $\begin{array}{c}\text { Trading } \\
\text { Value }\end{array}$ & $\begin{array}{c}\text { Turnover } \\
\text { ratio }\end{array}$ \\
\hline Government Bonds & 1,469 & $37 \%$ & 631 & 0.42 \\
\hline - Loan bonds & 1,406 & $26 \%$ & 628 & 0.60 \\
\hline - Savings bonds & 423 & $11 \%$ & 4 & 0.01 \\
\hline Treasury Bills & 228 & $6 \%$ & 1,500 & 6.58 \\
\hline State Enterprise Bonds & 491 & $12 \%$ & 84 & 0.17 \\
\hline - Guaranteed & 325 & $8 \%$ & 52 & 0.16 \\
\hline - Non-guaranteed & 168 & $4 \%$ & 32 & 0.19 \\
\hline BOT Securities & 897 & $22 \%$ & 1,968 & 2.19 \\
\hline - BOT bills & 586 & $15 \%$ & 1,445 & 2.47 \\
\hline - BOT bonds & 311 & $8 \%$ & 479 & 1.54 \\
\hline Sub-total Public Debt & 3,127 & $77 \%$ & 4,183 & 1.34 \\
\hline Corporate Debt Securities & 846 & $23 \%$ & 93 & 0.10 \\
\hline Foreign Issues & 16 & $0 \%$ & 2 & 0.10 \\
\hline Grand Total & 4,085 & & 4,277 & 1.05 \\
\hline Memo: Financing Transactions & & & 2,678 & \\
\hline
\end{tabular}

4. An over-riding factor impeding the development of more liquid fixed income markets in Thailand is the relatively limited demand for capital. This is true of Thai corporations, where private sector investment continues to be weak, but also of the public sector given the fiscal policy stance. Until the prospects for investment improve, this limited demand for capital, which is a key determinant in the supply of debt, coupled with the ample liquidity in the banking system, will continue to constrain activity in both the primary and secondary markets. Nevertheless, there are a number of structural and regulatory impediments that should be addressed now, which will enhance the positive impact of issuance, however limited, and which will ensure that the Thai market is well positioned to address the future needs of a growing economy.

\section{The Primary DebT Market}

5. The primary fixed income markets comprise the primary market for public debt securities and the corporate debt market.

\section{A. Public Debt Instruments}

6. The public debt market is dominated by government securities. Of the total B 3,085 billion outstanding of public debt securities, Treasury bills and government bonds represent 55 percent. These instruments are issued by the Public Debt Management Office (PDMO) in line with the provisions of the Public Debt Act (PDA). The PDA allows debt to 
be raised for the following purposes: to finance (i) the budget deficit; (ii) approved social and economic spending; (iii) debt restructuring; and (iv) onlending. ${ }^{3}$

7. There are two types of government bonds: loan bonds and savings bonds. Loan bonds are standard wholesale government bonds, issued at fixed rates at tenors out to 20 years maturity. Despite recent efforts to build some market benchmarks, which include the commitment to create and maintain benchmarks of at least B 40 billion at 7 and 10 years over the period 2006-2010, the current stock of government loan bonds remains fragmented. As at end-December 2006, there were 30 different issues of loan bonds outstanding, with an average size of B 35 billion. At that time, only 3 bonds exceeded B 40 billion in size, and 7 were less than B 30 billion; market sources indicate that the desired size of a benchmark would be at least B 50 billion.

8. Government savings bonds (GSBs) are effectively a retail product, sold directly to individuals in small denominations. Of the total stock of government securities, savings bonds make up around 25 percent. One bond-issued in 2002 to restructure some of the debt of the Financial Institutions Development Fund (FIDF) - accounts for almost half the total outstanding. ${ }^{4}$ This will redeem in 2012. There are also four other savings bonds of significant size, ranging from B 26 billion to B 54 billion, maturing in 2007, 2009, 2011 and 2014. As new issues of savings bonds tend to be much smaller, typically only B 500 million, their proportion may drop significantly. GSBs are currently sold with a tenor of 3 years.

9. Treasury bills are issued at one, three and six month maturities. At end-2006, they made up 13 percent of the portfolio of government securities. However, the PDMO intends to refinance a significant proportion of bills — around B 120 billion-with loan bonds in the current fiscal year (FY2007), ${ }^{5}$ which will reduce their proportion considerably.

10. The planned primary issuance program for FY 2007, envisages gross issuance of government bonds of around B 365 billion. Preliminary indications for FY 2008, indicates that gross issuance of bonds will decline to B 222 billion. At this level of issuance, the PDMO will only be able to support 4 new benchmark bonds a year. Coupled with the decline of the Treasury Bill (Tbill) stock and the anticipated strength of the budgetary position, this

\footnotetext{
${ }^{3}$ Debt restructuring refers to the refinancing of debt for the purposes of minimizing FX risk or smoothing the profile of debt repayments. Onlending refers to raising financing in the name of the government and then onlending it to approved agencies, such as local governments or state enterprises; currently onlending is restricted to external debt.

${ }^{4}$ The SB129A redeems on September 12, 2009. The value outstanding is B 206 billion.

${ }^{5}$ October 2006 to September 2007.
} 
suggests that the PDMO's activity in the primary market could drop significantly in the medium-term unless new debt creating flows can be generated (e.g., through active debt exchanges, expanding the scope of onlending to domestic debt, etc.). ${ }^{6}$

11. Complementing the PDMO issuance, the BOT issues ultra-short central bank bills and bonds for monetary policy purposes. As Figure 1 indicates, the issuance of BOT bonds far outstrips that of government bonds. As at end-Dec 2006, there were B 586 billion BOT bills and B 311 of BOT bonds; bills have maturities of less than 15 days and fixed rate bonds are issued at 1 and 2 years maturity, with new issues typically between B 50-70 billion in size. Additionally, in March 2007, the BOT introduced a 3-year floating rate note.

12. Finally, there are a number of State Owned Enterprise (SOEs) that issue bonds, most of which are government guaranteed. The Government Housing Bank is the largest of these issuers; as of end-Dec 2006, GHB had B 85.5 billion of bonds outstanding, 17 percent of this market segment. All GHB issues, barring one, are government guaranteed.

13. Note, these figures exclude securities issued by FIDF to meet its ongoing liquidity needs - these bonds are not sold outright but are solely used as collateral to support rolling repo transactions. The government has, over time, fiscalised the FIDF losses by issuing government securities and injecting the proceeds into FIDF, reducing FIDF's need to issue in its own name. These capital injections are based on a regular assessment of FIDF's expected loss, taking account of an updated valuation of its assets.

14. All retail savings bonds are issued in scrip (or certificated) form, while wholesale instruments are issued in scripless (or dematerialised) form, but with an option to be held in scrip (or certificated) form. As of end-April 2007, 31 percent of stock was held in scrip form. One reason that so much is held in this form is that securities can be pledged as collateral to support loan applications, electrical consumption applications, used as bail, or by insurance companies as legal reserves pledged to the Department of Insurance. Currently, the legal provisions of the Civil and Commercial Code require collateral to be pledged in the form of scrip securities. However, related Acts are being reviewed in order to allow for scripless securities to be pledged as collateral to a greater extent. Investors may also choose to hold their securities in scrip form to avoid the custody or depository costs.

\footnotetext{
${ }^{6}$ Although issuance of domestic debt could increase by around B 60 billion over FY 2008 and FY 2009 to meet the financing of the planned mass transit investment. This is based on an assumption that JBIC will provide a loan to meet the remaining cost to the central government - anticipated to be around B 90 billion.
} 
Figure 1. Thailand: Issuance of Government and BOT Bonds 2006 and 2007

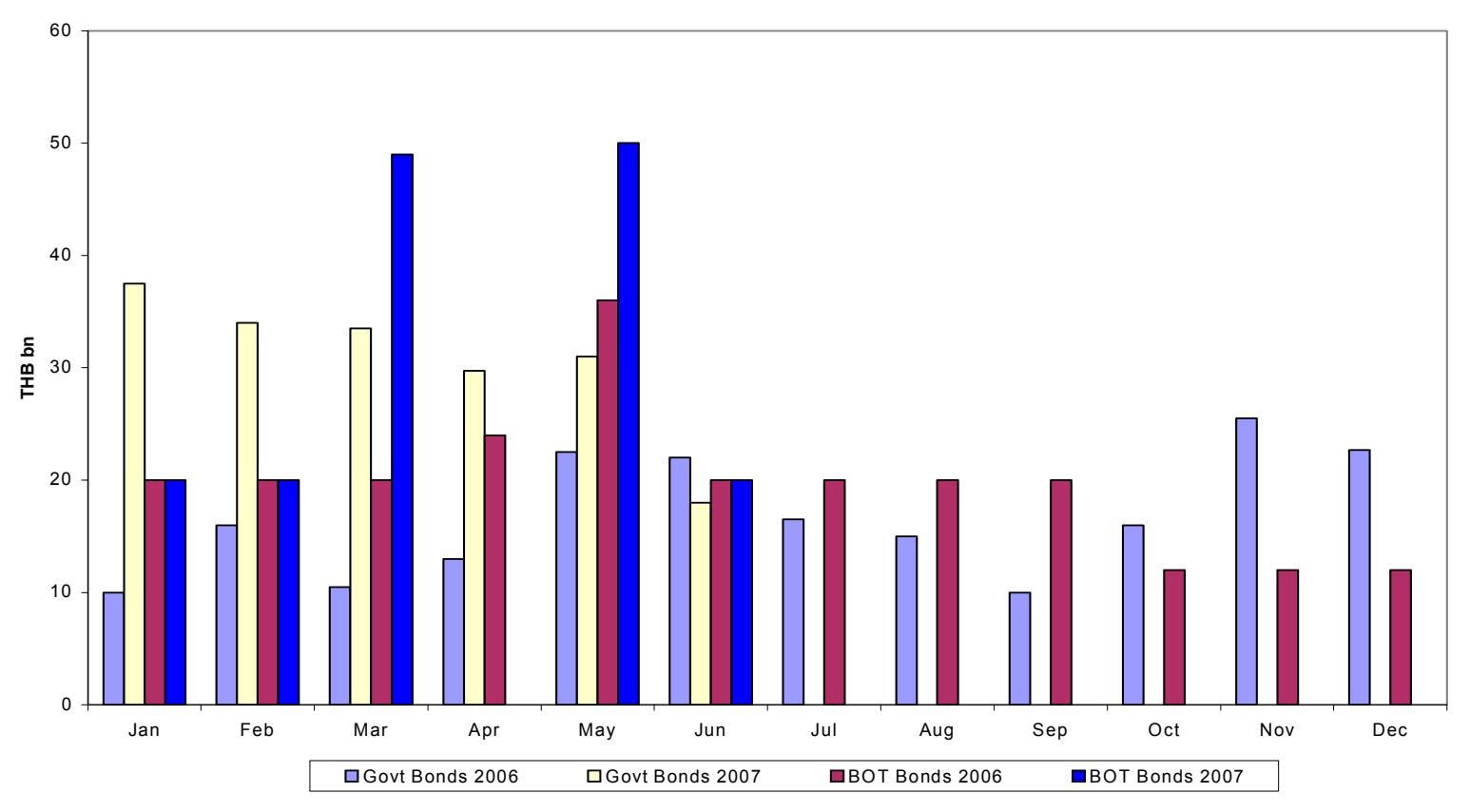

Source: BOT.

\section{B. Primary Market for Public Debt}

15. With the exception of the GSBs, which are sold to retail investors at a fixed price and distributed through one of the commercial banks, both the PDMO and BOT use multiple price auctions to issue their debt securities. Competitive bids can be submitted by all banks and other financial institutions, as well as the Government Pension Fund, the Social Security Office, life insurance companies, provident funds, and co-operatives. These entities are also eligible to submit noncompetitive bids; however, if they choose to do so, they forfeit the right to submit a competitive bid. Foundations, charities and other nonprofit organizations can also submit noncompetitive bids. Twenty percent of the total stock on offer is reserved for noncompetitive bids; however, this is rarely used. The PDMO auctions Tbills on Mondays and bonds on Wednesdays. Auctions of central bank bonds can be held on Tuesdays, Thursdays and Fridays.

16. Typically the PDMO auctions a bond every week, with auctions of the 7-year benchmark in the second week of the month and of the 10-year bond in the fourth week of the month. Often two bonds are auctioned in the same day. Typical auction size is small, at only around B 5 billion. This contrasts with the BOT approach which up to May had 3 auctions of bonds a month of a typical size of B 20-30 billion; under the new schedule, announced in May, BOT will only have on average 1 bond auction a month. 
17. Both PDMO and BOT pre-announce their schedule of auctions. The PDMO announces its calendar of bond auctions at the end of the quarter for the forthcoming quarter; and its calendar of Tbill auctions two weeks in advance. Similarly, the BOT announces its auction schedule a month in advance.

18. Despite the improvements in the commitment to an auction schedule, issuance of government loan bonds remains highly cyclical and somewhat uncertain (Figure 2). This reflects the fact that PDMO issuance is tied closely to government cash needs. For example, in the last quarter of FY 2007, the PDMO has cancelled all further auctions of the 2024 bond, only maintaining issuance of the 7- and 10-year benchmarks in line with its earlier commitment. In the absence of more active cash management, and perhaps a more aggressive use of Treasury bills as part of cash management, the uncertainty surrounding predicting these cash needs reduces the PDMO's ability to be fully transparent about its issuance calendar. Market participants indicate that while they can adjust for gaps in the issuance schedule, more certainty and predictability would be welcome.

19. The PDMO acts as the issuing agent for SOEs. Again, these bonds are sold through an auction; however, it is a paper based, uniform price auction, with single bids submitted by the dealers by hand. The size of these issues is generally small-typically only B 1-2 billion - and is typically allocated to a single bidder.

\section{The Primary Dealer Function}

20. In common with many countries, the Thai authorities have established a system of primary dealers (PDs). ${ }^{7}$ Currently, the BOT manages the system, reflecting the fact that PDs were first appointed to be the BOT's counterparties in open market operations. There are currently nine PDs; all nine are banks as securities companies do not meet the capital requirements. As the roles and responsibilities of the PDs have expanded, particularly with respect to the requirement to provide liquidity in the government securities market, the PDMO is taking a more active role in the system. In brief, the principal responsibilities of PDs are: to participate in the government securities auctions and the BOT's OMO outright sales; to make markets in the secondary markets for government securities; and to submit reference yields on government securities to ThaiBMA at the end of each day. The principal benefits are: the right to participate in meetings with the authorities; the right to be the BOT's

\footnotetext{
${ }^{7}$ In fact there are two sets of (overlapping) primary dealers - one set for outright transaction and one for bilateral repo transactions. It is the first set we focus on here; the second are used as the BOT's principal counterparties for monetary policy implementation. This is similar to the situation in many countries where the primary dealers in the government bond market may be different, although overlap with, the central bank's counterparties for open market operations.
} 
counterparty in the secondary market for government securities; and access to the Security Position Adjustment Facility (SPAF).

Figure 2. Thailand: Monthly Issuance of Government Bonds

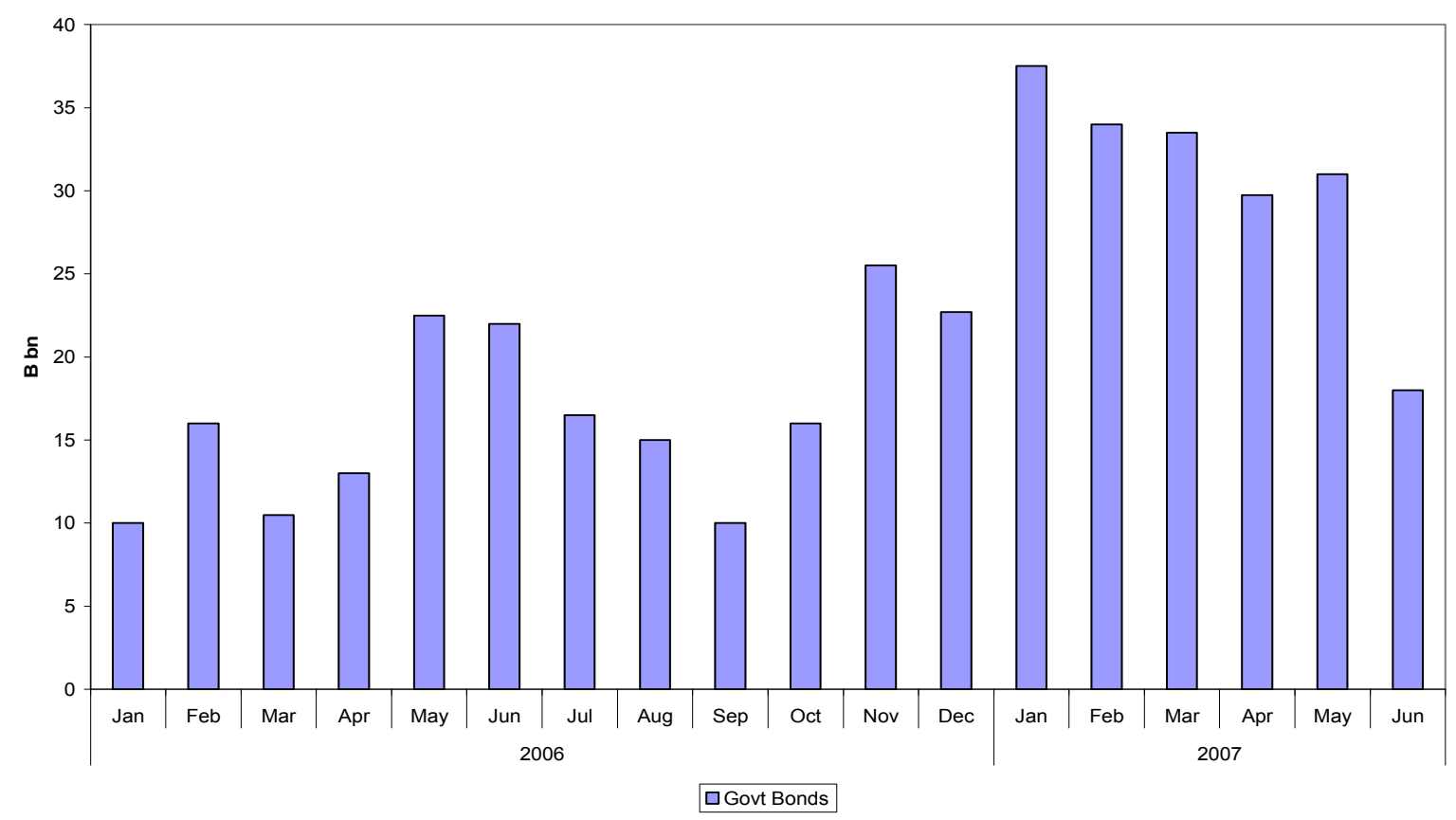

Source: BOT.

21. However, the current framework does not appear to be effective, particularly in terms of providing liquidity in the secondary market. In terms of the secondary market, PDs accounted for only 37 percent of activity in the last year. ${ }^{8}$ This reflects two factors: (i) dealers do not maintain large trading books (sources report that most of their bonds are held in their "held-to-maturity" portfolio); ${ }^{9}$ and (ii) given the frequency of auctions, it is essentially a "broked" market with investors securing stock in the primary auction rather than accessing the secondary market. Here PDs will take account of client bids, typically those of mutual funds, when submitting bids in the auction. ${ }^{10}$ Since there is an auction almost every week,

\footnotetext{
${ }^{8}$ Based on figures provided by the PDMO.

${ }^{9}$ One source indicated that they only typically held B 100 million of the "on-the-run" securities on their trading book; this would only cover $4-5$ typical trades.

${ }^{10}$ Where institutions do not have direct access to the auction, PDs should submit their bid in the price and quantity indicated by the client - effectively acting as a broker. The benefit for the PD is access to information
}

(continued) 
fund managers can manage cash flow and invest new funds by purchasing in the primary offering. Reducing the frequency of auctions would change the dynamics of the market considerably and would generate a need for more meaningful market making services to be provided. This should spur a review of the PD framework to ensure that it is "fit for purpose."

22. Before determining the appropriate mix of benefits and obligations, the authorities should be very clear about what they are trying to achieve. For example, in 2003, the Brazilian National Treasury jointly with the Central Bank reviewed the primary dealer framework to align it more closely with a desire to build a more liquid market. At that time, they introduced a "second-turn" or "green shoe option" which gives PDs the option to acquire additional stock following an auction, at the clearing price of the auction. Each PD's access to this option is determined on the basis of their performance in the primary and secondary markets. The authorities report that this change in the PD system has had the desired impact on behavior in the secondary market.

23. In terms of redefining the market making requirements, the PDMO could consider adopting the approach common in many European government bond markets, where the authorities specify the trade size and quote spread that the PDs have to meet. However, changing the frequency of auction will change the risk dynamics of the market considerably, and the current level of liquidity may not be a good indicator of the extent of the scope for improvement. Consequently, at this stage it would be difficult to determine what an appropriate spread might be. Instead, the PDMO might want to consider maintaining a general requirement to provide firm two-way quotes to clients in the benchmark stocks but ensuring that competition and the PDs' incentive structure is such that the "normal" spread emerges in the market. ${ }^{11}$

24. It would be appropriate to match any tightening of market making obligations to an improved set of benefits. Typically, market making obligations would be accompanied by the exclusive right to submit bids in the auctions, be the authorities' counterparty in any

on order-flow, which can inform and benefit their own bidding strategy. Note market sources indicated some instances where client bids were effectively adjusted by the PD. For example, even if a client had bid above the cut-off price for the auction, the dealer did not necessarily allocate the full quantity of their bid. If this is a common phenomenon, it would be of grave concern and would effectively constitute an abuse of their privileged position.

${ }^{11}$ In addition, the current electronic trading system used in the wholesale market - the FIRSTS - does not appear to be sufficiently robust or fast to support the implementation of such an obligation. 
secondary market operations, and participate in meetings with the authorities. ${ }^{12}$ In addition, other incentives such as access to a "green-shoe option," a noncompetitive bidding facility or direct payment of fees could be considered. ${ }^{13}$ Such benefits could be the principal mechanism to incentivise the provision of market-making services in the secondary market. For example, the PDMO could instead allocate, say, 10 percent of the amount currently available for general noncompetitive bids for the PDs. Access to this pot could be determined on the basis of their performance and scored on a range of factors. These might include (i) participation for their own book in the primary auctions; (ii) share of total secondary market trading with clients; ${ }^{14}$ (iii) provision of liquidity to individual investors on Bond Electronic Exchange (BEX), particularly holders of GSBs; ${ }^{15}$ and / or (iv) market share of activity with customers in the corporate debt market. Data recorded by the TBMA should provide sufficient information to track performance here. The weighting of each factor should be determined based on the PDMO's assessment of priorities, in consultation with BOT; the resultant weighting system should be explicit and clearly communicated to existing and prospective PDs.

25. Finally, full market-making services could lead to PDs inadvertently going short, generating a need for a mechanism to cover that risk. Although the BOT enhanced the facility in May 2006, market participants indicate that the existing SPAf, which allows PDs to repo bonds from the BOT for up to one month, does not meet their needs. This may reflect the limitations of the BOT's portfolio with the bonds available for borrowing not those PDs want to borrow. A more effective mechanism might be the creation of a suitable PDMO portfolio from which bonds could be lent, at short tenors. ${ }^{16}$ At a minimum, that portfolio would need to hold quantities of all the on-the-run bonds. The PDMO could create a suitable portfolio by retaining some stock on its books from each auction - the German authorities did something similar; alternatively the PDMO could explore its scope to readily create (and

${ }^{12}$ Exclusive access to the auction should be accompanied by a clear commitment to pass investors' bids directly through to the auction without interference.

\footnotetext{
${ }^{13}$ Access to a non-competitive bidding facility is a common feature of many European primary dealer arrangements, while a "green shoe" option is used by Brazil and Mexico. Both Sweden and the Netherlands have used direct fees to reward PDs, with the overall pot allocated on the basis of the authorities' assessment of PDs relative performance.

${ }^{14}$ In addition, the authorities might want to consider giving FIRSTS activity some priority to improve market transparency. This could comprise "put-through" business, where users show ("put through") negotiated and transacted outside the platform, say over the telephone.

${ }^{15}$ The BEX provides an electronic order book for retail transactions.

${ }^{16}$ In many of those countries that provide such a special repo facility, such as Australia or the United Kingdom, the tenor is only overnight, with a right to rollover.
} 
subsequently cancel) new bonds on demand, as in the United Kingdom. In addition, this facility could be supplemented by the flexibility for the PDMO to "tap" a bond at short notice to address a general level of excess demand in the market. However, as this would be at the PDMO's discretion, it may not help specific PDs address their specific need to rebalance their positions.

\section{Primary Market for Corporate Debt}

26. The Thai corporate debt market is substantially smaller than the public debt market, representing about 15 percent of the total debt issued and outstanding. In 2006 outstanding corporate debt registered with the TBMA totaled B 846 billion, including B 237 billion of short-term commercial paper. The remaining long-term debt is heavily weighted to bonds with maturities of five years or less (B 475 billion). A very small amount of debt, B 24 billion, is of tenors 10-years or longer.

27. In addition to being small in size, it is relatively homogenous, largely comprised of medium term notes and short-term commercial paper issued by investment grade rated banks or companies. In fact, 93 percent of all outstanding corporate debt is rated A or better by one of the two Thai rating services. ${ }^{17}$

28. In 2006 there were 73 new corporate bond issues totaling B 145 billion. Individual issues ranged from B 50 million to B 25 billion with the tenor of the majority of issues three years or less. In 2006, B 737 billion of commercial paper was issued.

29. Overall, the limited size and uniformity of the Thai corporate debt market is a reflection of the prolonged weakness in private investment, which has limited corporations' demand for capital. However, 3 other factors are important: (i) institutional investors are interested only in purchasing investment grade debt rated A or above, in large measure because prudential regulatory policies substantially restrict institutions ability to purchase below investment grade debt; (ii) the primary underwriters of debt in Thailand are banks, which can provide bank loans as an alternative on competitive terms and may have a business preference for making a high quality commercial loan rather than underwriting a debt issue; and (iii) prudential regulatory restrictions limit or prohibit sub-investment grade companies and unrated public and private companies from issuing debt. ${ }^{18}$ These regulatory limits also apply to public issues of short-term commercial paper by companies in Thailand.

\footnotetext{
${ }^{17}$ Note, Thai rating service standards differ somewhat from international rating standards.

18 "With regard to the supply of corporate bonds, the limited number of large, quality corporate issuers with financial standings strong enough to meet the rigorous public disclosure and external rating agency requirements results in a higher all-in cost of funding through debt issuance relative to bank lending for most
}

(continued) 
30. Even some companies with an investment grade rating may have difficulty issuing debt. While the two Thai rating services consider a BB rating to be investment grade, Thai institutional investors are reluctant to purchase debt issues rated below A. Institutional investors believe they need a "margin of safety." In the event that a bond is downgraded from $\mathrm{A}$ to $\mathrm{BBB}$ or $\mathrm{BB}$, an institution may continue to own it. However if a bond is downgraded below $\mathrm{BB}$, an institution may be required to sell it. In an illiquid market this may be difficult or may result in a significant investment loss. For this reason, investors prefer to have a "rating cushion" to avoid this problem.

31. According to one of the Thai rating agencies there are approximately 100 Thai companies that would qualify for an investment grade rating. However a substantial number of these ratings would be below the A rating that the institutional investor community wants. As a result the number of Thai companies that actively issue debt is approximately only 25 . Such a small number creates an additional problem for investors as Thai regulatory policy imposes concentration limits on the amount of debt that an institution may own from a single issuer.

32. Five major banks dominate corporate bond underwriting. As the banking system in Thailand has a surplus of liquidity available for commercial lending, the underwriting function at these banks is in direct competition with the bank's commercial loan origination business. As a result, these intermediaries do not appear to actively promote underwriting as a business priority.

33. Thai corporations rely primarily on commercial bank lending, internal cash flow or the borrowing power of foreign parent companies to meet investment capital needs. Thai banks typically lend funds at a rate that is fixed for only six months and floats thereafter. Thai companies often engage in an over-the-counter (OTC) interest rate swap (IRS) to convert the floating rate to a fixed rate.

34. Despite the fact that the transaction costs associated with an offshore offering are typically substantially greater than an offering in Thailand, ${ }^{19}$ several Thai companies have

firms. This problem was compounded by the fact that banks, which derive a large part of their profits from lending, were reluctant to underwrite bond issues. As a result, only a limited number of issuers (mainly companies with strong credit profiles) were able to obtain funding from this market." Ruengvirayudh and Panyanukul (2006), "The Corporate Bond Market in Thailand", Bank for International Settlement Papers No. 26. pp 154.

${ }^{19}$ Industry professionals in Thailand explained that offshore deal costs are greater because the disclosure requirements are greater, underwriters have greater due diligence obligations and legal fees are higher. 
chosen to access external markets, successfully issuing large bond offerings offshore. Several explanations were given for the use of offshore financing. Anecdotally we have been told that it is difficult to issue a debt offering greater than US\$20 billion in the Thai market due to the limited number of large institutional investors, each of which must comply with regulatory concentration limits placed on the key institutional investors. ${ }^{20}$ Other explanations for offshore financing included the legal prohibitions on below investment grade offerings and the lack of market interest in longer maturity notes. ${ }^{21}$

35. In 2005 there were six offshore offerings by Thai corporations totaling B 56.3 billion and in 2006 there were eight offerings totaling B 60.4 billion. The total value of these 14 issues, B 117 billion, is significant. It is the equivalent of almost 20 percent of the total value of all registered long-term corporate debt outstanding in the Thai secondary market. Reliance upon offshore markets for very large debt offerings further reduces the supply of debt available for trading in the secondary market and thus reduces secondary market liquidity. ${ }^{22}$

36. Foreign issuers of baht denominated debt have very limited access to the Thai debt market. Under Ministry of Finance (MOF) regulation 42/2006 only the following may issue baht denominated debt: (i) international financial institutions, (ii) foreign governments, (iii) financial institutions of foreign governments, (iv) corporations from ASEAN+3 countries, and (v) other foreign corporations deemed appropriate by the MOF. Prior approval is required from the MOF for the tenor and amount of the offering, the use of proceeds, and the issuer rating. Issues must be for tenors longer than three years If the issuer intends to transfer funds offshore, the MOF requires that the proceeds must be converted from baht into a foreign currency. A joint committee comprising MOF, BOT and Securities and Exchange Commission (SEC) has been established to consider applications to issue baht-denominated securities by foreign issuers, based on guidelines approved by the Minister of Finance. The committee meets semi-annually.

\footnotetext{
${ }^{20}$ Most financial regulatory systems impose concentration limits on institutional investors. These limits often take two forms, a limit on the amount of a single offering that an investor may purchase and a limit on the total amount purchased of securities offered by a single company. There is nothing per se improper about concentration limits but the may have unfortunate consequences in smaller markets. For example the largest company on the SET, Thai Petroleum represents 10 percent of the total market capitalization of the SET. In some countries, a concentration limit of less than 10 percent would make it impossible to create an index fund that reflected the SET. For this reason, regulatory authorities may create a process through which mutual funds can obtain a waiver from a concentration limit when there is an appropriate basis for seeking relief.

${ }^{21}$ See discussion on the nature of demand below.

22 "Liquidity divided is liquidity lost. Every baht bond not traded in Bangkok would be one less bond that could be repurchased there or that could form part of a benchmark bond there, making the domestic market that much smaller and less liquid." McCauley and Park (2006), page 36.
} 
37. The MOF has approved a total of 5 debt offerings under this regulation. The Asian Development Bank has made three offerings for a total of B 10.5 billion. The Japan Bank for International Cooperation has made one public offering of five year notes for B 2 billion and Citigroup issued B 2.6 billion of five year notes in a private placement.

\section{E. Primary Market Factors Affecting Secondary Market Activity}

38. The structure of supply can impede the development of the secondary market. As discussed above, the public debt market remains relatively fragmented and the corporate debt market is small. This results in a general lack of effective benchmarks - to price other related securities, provide an alternative tool to hedge other exposures, or to provide the building blocks for more tailored derivative products, and renders the yield curve fragile.

39. The frequency of government auctions is one of the key impediments to greater activity in the secondary market for public debt. Fund managers can readily manage new inflows into funds with no more than a few days to wait between new issues. This means they rarely go to the dealers to acquire instruments in the secondary markets; limiting the need for dealers to maintain significant inventories on their trading books. Recognizing this, the BOT has gradually been reducing the frequency, while increasing the size, of its auctions of BOT bonds; in May 2007, it announced that it would only auction 1-year bonds once a month (from twice a month) and 2-year bonds on a quarterly basis (from monthly).

40. Reducing the frequency of, and increasing the size of, auctions of government loan bonds could lead to greater activity in the secondary market. For example, the PDMO could follow the BOT lead and have on average only 1 or 2 bond auctions a month, say issuing the 7- and 10-year benchmarks, which are very similar in duration, every other month. If the financing need supports it, the PDMO could then add a 5-year or 15 / 17-year, again on alternating months. Ideally, there would only be one bond of similar duration offered a month, which would suggest pairing the 7-year bond with the long bond and the 5-year bond with the 10-year bond. This could lead to an increase in average issue size of B 10-15 billion to achieve the current average total issue size.

41. Changing the size and frequency of auctions would require PDs to provide greater underwriting services in the primary market, as they would need to warehouse the inventory until fund managers needed it. Fund managers would then acquire stock from PDs in the secondary market. As this would require PDs to commit greater risk capital to the market, there is a risk that behavior may not change if the incentives are not well aligned (see section on primary dealers). This could result in uncovered auctions and lower returns for fund managers as they seek alternative short-term investments to bridge the gap between auctions. 
42. Establishing larger, more effective benchmarks would also have a beneficial effect. In that respect, the PDMO's medium-term commitment to establish benchmarks at 7 and 10 years is welcome. However, consolidating some of the existing issues could quickly establish some additional benchmarks. ${ }^{23}$ More generally, given the potential limited issuance over the medium-term, the PDMO needs to consider, in conjunction with market participants, how many benchmarks it can credibly maintain and at which key points on the yield curve should those benchmarks be established.

\section{F. Other Related Fixed Income Markets}

\section{Repo Market}

43. The Thai money markets comprise the market for unsecured money, synthetic term money and repo. The principal feature of the money markets is the ample liquidity of the Thai banking sector. This obviates their need to actively use the money markets, particularly the term money market, to fund their activities, limiting activity in the markets. In addition, market contacts report that, due to the distortions introduced by the Specific Business Tax (SBT), where term money market trades are executed, these are generally effected through synthetic money market positions, i.e., through the foreign exchange (FX) forwards market. However, apart from this factor, the principal concern expressed by market contacts related to the functioning of the repo markets, and the private repo market in particular.

44. Overall, the BOT plays a dominant role in the repo market. The repo market is actively used by the BOT to implement monetary policy - through its bilateral repo operations. In addition, the BOT operates the BOT repo market, effectively acting as a central counterparty for interbank repo. However, in 2006, the BOT announced its intention to close this market in order to promote the development of a private repo market.

45. A successful transition to a private repo market requires industry agreement on a number of technical factors including agreeing a standard master agreement - a Global Mater Repurchase Agreement (GMRA), appropriate collateral management functionality within the securities depository, regulatory agreement on collateral and margining rules and counterparty risk management. While the required enhancements to the Thailand Securities Depository CO., Ltd. (TSD) appear to have been implemented, market sources report that, despite BOT's best efforts, progress on resolving other technical issues remain seems to have stalled. This is impeding market participants' ability, in particular, to execute the GMRA with counterparties. In addition, there are a number of potential regulatory impediments

\footnotetext{
${ }^{23}$ The PDA effectively constrains the PDMO's ability to do this. This is not one of the permitted reasons for debt restructuring.
} 
which may restrict certain market participants' ability to participate on equal terms. ${ }^{24}$ Although several industry representatives expressed a desire that the MOF, BOT, and SEC take leadership in addressing these issues, BOT has requested that the Financial Market Association (known as ACI club) take on this role.

\section{Derivatives}

46. Market contacts report that the IRS market is very active. Market participants also note that the nondeliverable IRS has become very active in the last 6-12 months, partly as a consequence of the restrictions placed on foreign investors' entry into the Thai market directly. Foreign banks with a presence in Thailand appear to intermediate effectively between both the on- and offshore markets, equating prices across both. Thai domestic banks have a limited presence in the international swaps market, as they typically do not meet international counterparty risk standards.

47. The Thai Futures Exchange (TFEX) is the only financial futures/derivatives exchange in Thailand. It is a wholly-owned subsidiary of the Stock Exchange of Thailand (SET). At present, there is only one derivative product traded on the TFEX, an index future based on the SET 50 (composed of the 50 largest cap listed companies). The next planned product will be an option on the SET50 index.

48. TFEX has been planning to introduce an interest rate futures contract. It was expected that the contract would be launched in 2006, however, it has been delayed until decisions are reached on the structure of the contract, determining whether the contract should use a single bond offering or a basket of bonds as the underlying security and whether the contract should be based upon a short-term or long-term interest rate.

49. It was suggested that this delay partly reflects the fact that TFEX is owned and run by brokers, who are not active in the fixed income markets. Those market participants that would benefit most from access to an interest rate futures contract — such as mutual funds or banks - consequently have a limited say in the timing of various product launches, etc. In addition, unless banks have direct access to trading on the exchange, such a contract is unlikely to succeed.

50. Government regulatory policy also has been an impediment. Under SEC regulations mutual funds may use derivatives only for cash management and limited portfolio hedging.

\footnotetext{
${ }^{24}$ For example, the insurance regulator has set a minimum haircut that must be applied to all repo transactions that an insurance company enters into. This may restrict their ability to compete on favorable terms.
} 
The Department of Insurance requires its prior approval for insurance companies to engage in IRS.

51. The continued lack of an effective interest rate futures contract impedes market participants' ability to hedge their positions. This is one of the impediments to greater secondary market liquidity (see below). In Thailand this is compounded by the inability of intermediaries to engage in short selling, because of the lack of a ready borrowing facility. However, the recent enhancements of the TSD system to provide a lending facility in conjunction with its assumption of clearance and settlement responsibilities for the repo market should help address this.

\section{The SECONDARY DebT MARKeT}

\section{A. Secondary Market Activity}

52. Thailand's secondary debt market is less liquid and less active than other countries in East Asia (see Figure 3). It ranks among the lowest in daily trading volume, and average size of trades and its typical bid-ask spread is typically one of the widest.

53. As Table 2 indicates, despite the size of the public debt securities market, activity in the secondary market is poor. The most actively traded instruments are the shorter-dated instruments, particularly the bills. Savings bonds are the least traded instrument, which is not surprising given the nature of demand. The average number of trades in loan bonds was 4950 on a daily basis in 2006 , with an average trade size of B 53 million. $^{25}$

54. The secondary market for corporate debt is extremely limited. While corporate debt represents 15 percent of all debt issues registered with the TBMA, it generates a minimal amount of daily trading volume. The TBMA estimates that in 2006 there were on average only 18-19 trades in corporate issues daily, with an average trade size of B 20 million. The total value of all corporate bond transactions in 2006 was only B 92.5 billion, a little more than 15 percent of the total outstanding value. ${ }^{26}$ This compares with an average number of $3-$ 4 trades in SOE bonds of average size of B 96 million.

\footnotetext{
${ }^{25}$ Note in this section the reported number of trades and trade size are based on aggregated trading data, i.e. they include both outright and financing transactions. The impact of these financing transactions is likely to greatest in the public debt market. Nevertheless, the figures do provide an indication of activity in the outright market.

${ }^{26}$ Total outstanding value of corporate bonds was B 609 billion.
} 
Figure 3. Thailand: Indicators of Liquidity in East Asian Bond Markets

Size (x-axis) and trading volume (y-axis) ${ }^{1}$

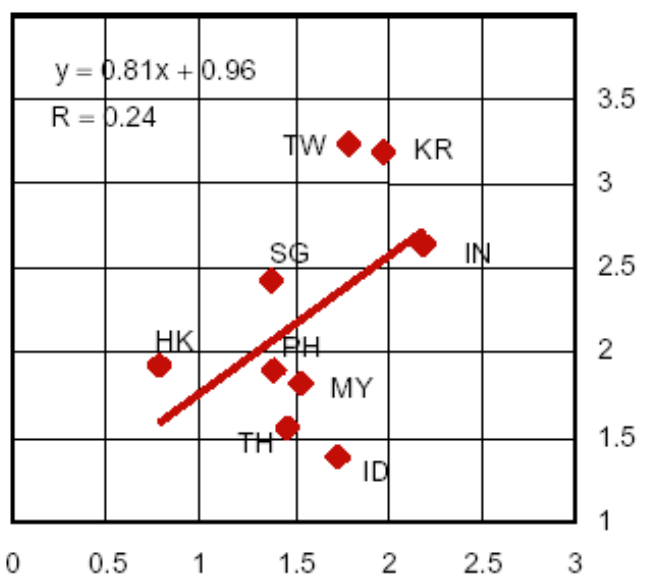

Issue size $(\mathrm{x} \text {-axis })^{1}$ and bid-ask spread (y-axis) $)^{2}$

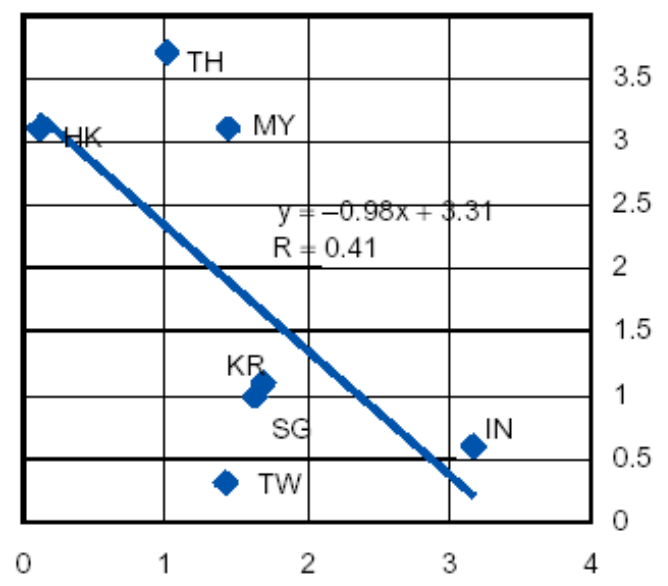

Trading volume (x-axis) $)^{1}$ and bid-ask spread $(\mathrm{y} \text {-axis })^{2}$

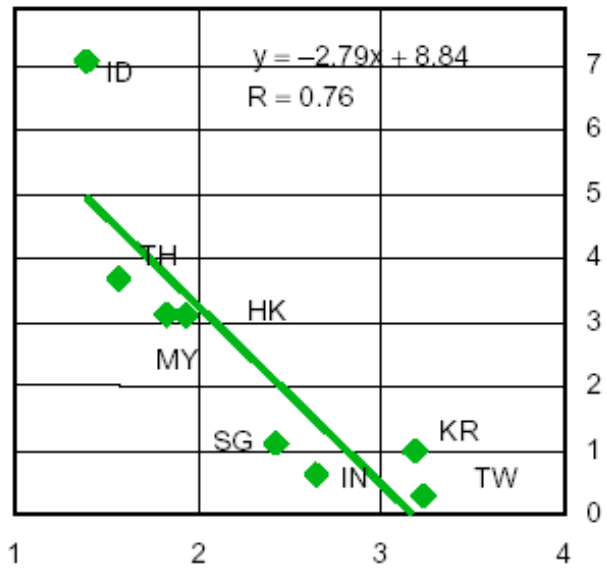

Concentration of bond holdings ( $\mathrm{x}$-axis $)^{3}$ and bid-ask spreads (y-axis) ${ }^{2}$

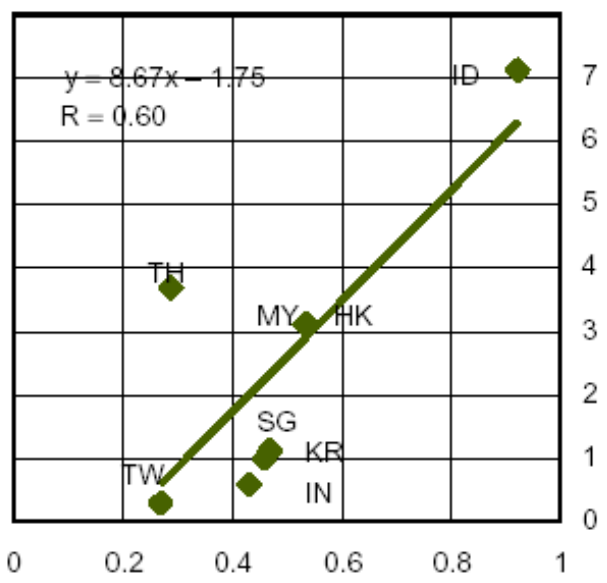

${ }^{1}$ In billions of US dollars; in logs. ${ }^{2}$ In basis points. ${ }^{3}$ Herfindahl-Hirschman index.

Sources: Barclays Capital; Bloomberg; Deutsche Bank; HSBC; BIS calculations.

55. Issues from foreign issuers, such as the Asian Development Bank (ADB) and Japan Bank for International Cooperation (JBIC) issues, were intended to contribute to secondary market activity but have contributed little. In 2006, the average daily trading volume was B 6.59 million and the annual turnover rate was 10 percent. 
56. While there is a significant amount of commercial paper issued by Thai banks and corporations, it is typically bought and held to maturity. Medium and longer term corporate notes are in such short supply that institutions buying in the initial offering rarely have an incentive to trade them in the secondary market, as there is little if any comparable notes available for replacement.

\section{B. Secondary Market Infrastructure}

57. Secondary market activity takes place in both the OTC market and on-exchange. The on-exchange market - the BEX - is an electronic market targeted at small, retail transactions. In the period Jan - July 2006, average trade size was of the order of B 4 million with an average monthly trade value of B 21 million. Liquidity is provided by authorized dealersnot necessarily the PDs, with clients hitting or lifting advertised bids or offers. They cannot submit their own quotes. In addition, the exchange provides an electronic platform - the Fixed Income and Related Securities Trading System (FIRSTS) - to the OTC market. This mimics the OTC trading functionality, providing both a platform for inter-dealer trading and for dealer-wholesale client trading. Again clients are not permitted to post their own bids or quotes but can only absorb the liquidity offered through the platform; however, the technology does allow clients to send a "request for quotes" (RFQ) to multiple dealers at once and to conduct bilateral negotiations off-line. ${ }^{27}$ FIRSTS was officially launched by BEX on March 1, 2006. ${ }^{28}$ In the period Mar-July 2006, average trade size was B 63 million, with an average monthly trade value of B 20.6 billion. Overall, trading is concentrated in the OTC wholesale market (approx. 98 percent of trading), with most of that being conducted over the telephone rather than on the FIRST system (93 percent telephone relative to 5 percent through FIRSTS).

58. All trades in bonds registered by the TBMA must be reported to the TBMA within 30 minutes. The TBMA publishes trade reports for government securities upon receipt and twice daily for corporate bond trades.

\section{Secondary Market Intermediaries}

59. A limited number of Thai banks operate trading desks and engage in proprietary trading in the secondary debt market. As with their limited operations in the government

\footnotetext{
${ }^{27}$ The time delay between information transmittal is reportedly one of the impediments to greater use of the system; however, BEX is planning a systems upgrade which should reduce the time lag from around 10 seconds to around 3 seconds.

${ }^{28}$ The system was developed by the TBMA, who subsequently sold the platform to BEX when it became the self-regulatory organization (SRO) for the market.
} 
secondary market, these banks do not actively provide liquidity or serve as market-makers for corporate debt. Most secondary trading is done on an agency, or riskless principal, basis rather than by banks or brokers operating as dealers or market-makers, committing risk capital to the market. Many factors contribute to this. These include: the limited supply and size of debt products - a factor even in the public debt markets; the lack of a cheap and efficient borrowing/lending mechanism; and the lack of standardized interest-rate derivatives that can be used to hedge interest-rate risk. The lack of active intermediaries competing for market share in turn increases the transaction costs and widens the spreads in the debt market. In this respect Thailand's market is similar to many other Asian debt markets. "There is no evidence of any formal inter-dealer market or of inter-dealer brokers who specialize in corporate bonds. Thus, the secondary market for corporate bonds tends to be uncompetitive, resulting in wide bid-ask spreads that discourage trading. Market participants suggest that bid-ask spreads are about five to ten basis points, even for the most liquid issues." 29

60. Thai subsidiaries of foreign banks play an increasing role in the secondary market, notwithstanding their relative size and limited access to domestic sources of financing, including lack of access to a retail deposit base (Table 3).

61. Securities brokers play an even smaller role in the debt markets. Government policy has kept the number of licensed brokers in Thailand steady at 41 for more than a decade. New entrants must buy an existing license from a current registrant (typically a firm that is moribund with its license its only valuable asset). The industry operates under a standard business model that is based upon generating revenue from retail sales commissions, at rates that are set by the SET. It is estimated that the typical Thai securities firm generates 75 percent of its revenue from retail trading commissions. The steady flow of commissions, from largely riskless retail sales operations, has reduced the incentive for firms to allocate working capital to risky trading desks.

\section{THE INVESTOR BASE}

62. The 1997 financial crisis has had a significant and continuing influence on the Thai capital markets. Thai regulators have tended to adopt regulatory regimes that are ostensibly disclosure-based, but in fact impose significant prudential limits on Thai institutional investors. In turn Thai institutional investors believe that their underlying Thai individual investors are risk averse and cautious, and consequently have developed investment products that are conservative and designed to minimize risk, even at the expense of superior performance.

${ }^{29}$ Gyntelberg, Ma and Remolona, (2006), page 19. 
Table 3. Thailand: Most Active Dealers 2006

\begin{tabular}{|c|c|c|c|c|c|c|}
\hline & \multirow[t]{2}{*}{ Dealer } & \multirow{2}{*}{$\begin{array}{c}\% \text { Market Share } \\
\text { (Outright) }\end{array}$} & \multicolumn{4}{|c|}{ Trading Value (Billion Baht) } \\
\hline & & & Outright & Financing & Other & Total \\
\hline 1 & Kasikorn Bank Plc. & 14.57 & 813.26 & 311.57 & 19.20 & $1,144.03$ \\
\hline 2 & Siam Commercial Bank Plc. & 14.54 & 812.01 & 589.25 & 1.91 & $1,403.18$ \\
\hline 3 & Deutsche Bank AG & 8.82 & 492.60 & 2.59 & 0.51 & 495.70 \\
\hline 4 & Bank Thai Plc. & 8.08 & 451.00 & 13.57 & 0.85 & 465.42 \\
\hline 5 & Bangkok Bank Plc. & 7.63 & 425.84 & 380.60 & 0.00 & 806.45 \\
\hline 6 & Standard Chartered Bank & 7.29 & 406.89 & 61.92 & 12.71 & 481.53 \\
\hline 7 & Thai Military Bank Plc. & 7.17 & 400.20 & 0.78 & 8.00 & 408.99 \\
\hline 8 & $\begin{array}{l}\text { United Oversea Bank (Thai) } \\
\text { Plc. }\end{array}$ & 6.56 & 366.01 & 21.13 & 19.76 & 406.90 \\
\hline 9 & $\begin{array}{l}\text { The Hongkong and Shanghai } \\
\text { Banking Co., Ltd. }\end{array}$ & 4.84 & 270.19 & 137.28 & 0.00 & 407.47 \\
\hline \multirow[t]{3}{*}{10} & Citi Bank, N.A. & 4.35 & 242.83 & 8.55 & 0.00 & 251.38 \\
\hline & Other & 16.16 & 902.21 & 976.30 & 228.63 & $2,107.14$ \\
\hline & & 100.00 & $5,583.05$ & $2,503.55$ & 291.58 & $8,378.18$ \\
\hline
\end{tabular}

Source: SEC.

63. As is typical in most countries, institutional investors - insurance companies, mutual funds, and a small but growing private pension sector-dominate the debt market in Thailand. The insurance industry is the largest institutional investor sector with debt investments of B 813 billion (2006). Fixed income mutual funds are second with B 640 billion in debt investments, followed by provident investment funds (B 391 billion), the Social Security Fund (B 341 billion) and the Government Pension Fund (B 321 billion).

64. These institutional investors tend to move in unison and in one direction. They buy in the primary offering, hold to maturity and prefer short-term notes. This homogeneity is another factor limiting activity in the secondary market. Prudential regulatory systems for mutual funds and insurance companies limit the investment incentives to trade actively, engage in repos or other lending activities to improve performance, and invest in lower quality or longer-term notes. It has been suggested that this bias reflects the strong defensive posture of most Thai investors in mutual funds, who remember the losses incurred in the 1997-1998 crisis.

65. While the mutual fund industry in Thailand has increased significantly in size (Table 4), the products offered are quite similar. Bond funds make up the bulk of the products offered, followed by mixed funds (which will also include bond holdings). The bulk of these bond funds are held in public debt securities, typically Tbills or BOT bonds, making mutual funds one of the largest players in these markets. For example, as of end-Sept 2006, 
although mutual funds held only 1 percent of government loan bonds outstanding, they held 44 percent of all Tbills outstanding and 26 percent of BOT bills and bonds (Table 5).

Table 4. Thailand: Development of the Mutual Fund Industry

\begin{tabular}{|l|r|r|r|r|r|r|}
\hline \multirow{2}{*}{ Investment Policies } & \multicolumn{3}{|c|}{ No. of Funds } & \multicolumn{3}{c|}{ NAV (Million Baht) } \\
\cline { 2 - 7 } & $\mathbf{2 0 0 5}$ & $\mathbf{2 0 0 6}$ & Mar. 2007 & $\mathbf{2 0 0 5}$ & $\mathbf{2 0 0 6}$ & Mar. 2007 \\
\hline General Mutual Funds & $\mathbf{5 8 4}$ & $\mathbf{7 1 6}$ & $\mathbf{7 2 4}$ & $\mathbf{7 7 5 , 3 9 2}$ & $\mathbf{1 , 0 4 0 , 6 9 7}$ & $\mathbf{1 , 1 3 5 , 1 7 3}$ \\
Capital Protected & $\mathbf{5 4}$ & $\mathbf{1 1 2}$ & $\mathbf{1 2 0}$ & $\mathbf{4 9 , 8 3 7}$ & $\mathbf{1 0 4 , 3 7 1}$ & $\mathbf{1 0 4 , 1 6 7}$ \\
- Fixed Income Funds & 50 & 103 & 110 & 49,523 & 103,431 & 101,835 \\
- Mixed Funds & 4 & 9 & 10 & 314 & 940 & 2,332 \\
Non-Capital Protected & $\mathbf{5 3 0}$ & $\mathbf{6 0 4}$ & $\mathbf{6 0 4}$ & $\mathbf{7 2 5 , 5 5 6}$ & $\mathbf{9 3 6 , 3 2 6}$ & $\mathbf{1 , 0 3 1 , 0 0 6}$ \\
- Equity Funds & 151 & 164 & 172 & 82,565 & 89,752 & 96,186 \\
- Fixed Income Funds & 221 & 303 & 315 & 341,792 & 536,448 & 643,077 \\
- Mixed Funds & 150 & 124 & 104 & 282,044 & 263,867 & 243,092 \\
- Property Fund for Public & 8 & 13 & 13 & 19,155 & 46,259 & 48,651 \\
\hline
\end{tabular}

Source: SEC.

Table 5. Thailand: Holdings of Public Debt Securities, Q3 2006

\begin{tabular}{lrrrrr}
\hline & Banks & \multicolumn{1}{c}{$\begin{array}{l}\text { Mutual } \\
\text { Funds }\end{array}$} & $\begin{array}{c}\text { Insurance } \\
\text { Companies }\end{array}$ & $\begin{array}{c}\text { Pension and } \\
\text { provident funds }\end{array}$ & $\begin{array}{c}\text { Total } \\
\text { Outstanding }\end{array}$ \\
\hline Government & & & & & \\
Loan Bonds & 264,256 & 10,563 & 293,708 & 250,386 & $1,060,250$ \\
Tbills & 75,329 & 115,112 & 4,993 & 18,147 & 260,000 \\
BOT bonds & 344,552 & 199,829 & 9,689 & 78,227 & 780,695 \\
SOE bonds & 100,724 & 12,286 & 48,202 & 97,763 & 344,203 \\
\hline
\end{tabular}

Source: BOT.

66. Most fixed income funds are closed-end funds with short lifespans. This is reflected in their strong preference for short-term debt, where the net asset value (NAV) will be less sensitive to changes in yields and in which liquidity can be readily managed with a "buy and hold" strategy given the short redemption profile. The assets they purchase typically have maturity dates that coincide with the expiration of the fund, eliminating the need for active fund management. These funds could be significantly affected by the PDMO's plans to reduce the overall stock of Tbills and may have to diversify into longer-term bonds in order to maintain returns. This would be a positive outcome for the market, but would require underlying investors to develop a tolerance for some variability in the NAV, given that these funds will be of longer duration. Similarly, those funds that invest in corporate debt have a strong preference for short term notes and invest heavily in commercial paper, which they again hold to maturity and use for cash management purposes. Nevertheless, mutual funds 
are one of the most active participants in the secondary market, accounting for 28 percent of activity in 2006 .

67. SEC rules have contributed to the similarity in mutual fund products and the conservative investment strategies. Mutual funds may only hold 15 percent of assets in illiquid securities and no more than 5 percent of the assets may be issued by one entity. The definition of illiquid securities includes any bonds with maturities greater than three years, below investment grade corporate debt or unrated corporate debt. Mutual fund operators are prohibited from creating a below investment grade mutual fund.

68. The growth in mutual fund investments is due in part to government tax preferences. Profits from mutual fund investments are exempt form capital gains tax. This creates an inherent investment advantage for mutual funds that reduces the need for fund managers to seek higher investment returns in order to attract investors.

69. Insurance companies and pension and provident funds together account for half the holdings of government loan bonds and over 40 percent of holdings of SOE bonds). However, their holdings of shorter-term instruments are quite small—only 11 percent of BOT bonds are in their hands.

70. While insurance companies are active investors in the primary debt market, they are very small players in the secondary debt market. More than 60 percent of insurance industry assets are invested in government and corporate debt, typically bought in the primary offering. Yet the insurance sector accounted for only 3 percent of the trading in the secondary market in 2006.

71. There are few large private investors in Thailand with the sophistication and or the willingness to invest in a contrarian fashion. Private investment funds, open only to high net worth individuals, are a small but growing investor segment. As of February 2007, there were 1201 private funds under management with total assets of B 149 billion.

72. Large foreign investors that might be active have been discouraged from investing by capital restrictions and tax policies. The reserve requirements introduced by the BOT in December 2006, require foreign investors in debt instruments to maintain a 30 percent reserve in a non-interest-bearing account. These investors are also subject to a 15 percent withholding tax on income from corporate bonds (government bond holdings are exempted). Prior to December 2006, foreign investors held an estimated B 130 billion of Thai debt securities. Following the impositions of the reserve requirement, foreign ownership of debt securities declined to an estimated B 60 billion. 


\section{The Regulatory FramewOrK}

\section{A. SEC Regulatory Policy}

73. Thai regulatory policy substantially restricts institutions from investing in longer-term notes or diversifying portfolios among a wider range of issuers and interest rates. SEC regulation of mutual fund products reflects a similar prudential concern. Below investment grade debt funds are not permitted and existing corporate debt funds are restricted to owning 15 percent or less of total assets in below investment grade or non rated debt or long-term debt (maturities longer than three years). In practice, funds typically own less than the 15 percent maximum. Other restrictions limit the ability of a fund manager to use sophisticated hedging techniques to improve performance.

74. In this regard Thailand is similar to other Asian countries. The Asian Development Bank has noted that many Asian countries have developed a regulatory structure that imposes substantial prudential limitations on institutional fund managers, with the consequence that these restrictions significantly stifle the development of a liquid secondary trading market. In its report on bond market development in 2006, the ADB stated "The current regulatory environment discourages institutional investors from trading, rather than encouraging them to manage risk prudently. Institutional investors face strict prudential limits on the value of bonds they hold - minimum and maximum allowed levels are defined based on credit rating or a bond's currency. For pension and insurance funds, for example, there is a sizable minimum amount of local currency government bonds required in a portfolio, and in general, there is no alternative instrument allowed for insurance reserves. While these controls are meant to protect investor assets from fund mismanagement, they arose from market conditions in the late 1970s and, in the current environment, prevent fund managers from learning to manage market risk. This reduces market flexibility as funds then tend to "hold to maturity." In turn, this discourages the use of prudent trading strategies to rebalance portfolios to match liability profiles and changing market conditions. It also blocks the potential for greater market liquidity.",30

75. SEC regulatory policy on issuers has also emphasized the need for investor protection by restricting who can issue debt and what debt can be issued, limiting the ability of companies to use private placements for maximum benefit. SEC regulations limit a private debt offering (PP) offering to B 100 million and to no more than ten non-institutional

\footnotetext{
${ }^{30}$ Asian Bond Monitor, April 2007, page 26.
} 
investors. All PP offerings must be filed with the SEC and the TBMA. Because private placements are included in the definition of illiquid securities, mutual funds are limited in the amount they can purchase. Similarly the DOI imposes similar limits on insurance company investments in private placements. Institutions purchasing PP debt may not sell it in the secondary market unless the issuer registers the securities.

76. SEC policy on the issuance of short-term commercial paper is also restrictive and reflects a "merit-based" philosophy designed to eliminate investment risks rather than relying upon corporate disclosure to enable a free market to assess risks. Following a well-publicized commercial paper default by an unrated company, in 2005 the SEC adopted regulatory limits on the sale of short-term commercial paper. Only investment grade rated companies and banks may issue commercial paper through a public offering, although unrated issuers may sell commercial paper through a private placement to qualified institutional buyers (subject to the illiquid security limitations for mutual funds). Listed companies must file a short-form registration statement and unlisted companies must file a free-form registration statement containing audited financial statements and the issue must be rated with the TBMA. At least three asset management companies must purchase the first offering of the issue.

77. The Thai SEC has taken the initiative to relax its requirements on foreign investment grade issuers, that have obtained MOF authority to issue debt in Thailand. They are now permitted to use the same 3 -year shelf offering rules available to Thai issuers. ${ }^{31}$ Similarly, Thai issuers may now make a simultaneous foreign and domestic offering with the same debt credit rating.

\section{B. Initiative to Promote Securitization}

78. Thailand has supported efforts to develop securitized debt instruments for many years. In 1997 Thailand enacted a law providing for the creation of special purpose vehicles to promote private sector development of collateralized debt products. The law was amended in 2004 to address legal impediments. Since then there has been some interest but very few financings. Part of the delay may be a result of continuing concerns over the sufficiency of legal safeguards in the event of borrower defaults to ensure that creditor rights are properly transferred from the loan originator to the purchaser of the collateralized debt instrument.

79. As the Box 1 indicates, Thailand's laws on securitization lag behind other Asian countries in most areas, notwithstanding recent amendments designed to address these

\footnotetext{
${ }^{31}$ They can also use an English language prospectus if they are making a related offering in other markets.
} 
concerns. As a result, Thailand lags behind other Asian countries in the use of securitized debt to increase the depth and liquidity of its financial market (Figure 4).

\begin{tabular}{|c|c|c|c|c|c|c|c|}
\hline \multicolumn{8}{|c|}{ Box 1. Provisions for Securitization } \\
\hline & \multicolumn{4}{|c|}{$\begin{array}{l}\text { Sale, assignment, or other conveyance of } \\
\text { assets to securitization vehicles }\end{array}$} & \multicolumn{2}{|c|}{$\begin{array}{l}\text { Creation and } \\
\text { operation of SPV }\end{array}$} & \multirow[b]{2}{*}{ 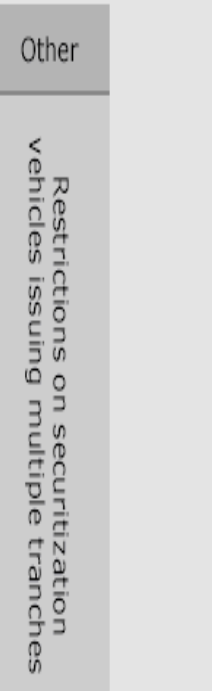 } \\
\hline & 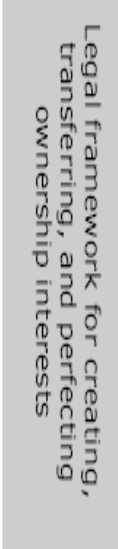 & 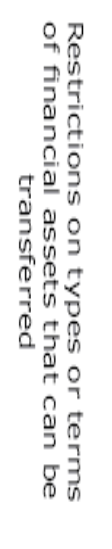 & 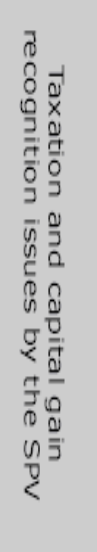 & 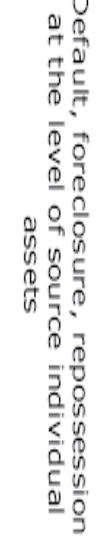 & 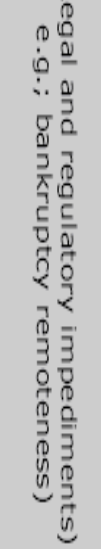 & 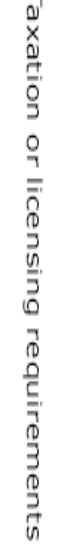 & \\
\hline Cambodia & NA & NA & NA & NA & NA & NA & NA \\
\hline China, People's Rep. of & $1 / 2$ & 1 & 1 & 1 & 1 & 2 & 1 \\
\hline Hong Kong, China & 5 & 5 & 4 & 5 & 5 & 5 & 5 \\
\hline Indonesia & 2 & 2 & 2 & 2 & 1 & 2 & 2 \\
\hline Korea, Rep. of & 5 & 4 & $3 / 4$ & 4 & 5 & 5 & 5 \\
\hline Malaysia & 5 & 4 & 4 & $3 / 4$ & 4 & 4 & 5 \\
\hline Philippines & $2 / 3$ & $2 / 3$ & $1 / 2$ & $2 / 3$ & $2 / 3$ & $1 / 2$ & $2 / 3$ \\
\hline Singapore & 5 & 5 & 5 & 4 & 5 & 5 & 5 \\
\hline Thailand & $3 / 4$ & 3 & $3 / 4$ & $3 / 4$ & $2 / 3$ & $4 / 5$ & $2 / 3$ \\
\hline Viet Nam & NA & NA & NA & NA & NA & NA & NA \\
\hline \multicolumn{8}{|c|}{ Source: East Asian Finance: Selected Issues (World Bank, 2006). } \\
\hline \multicolumn{3}{|c|}{$\begin{array}{l}\text { The table's assessments of the effectiveness of enabling } \\
\text { legal provisions (column 2), the enforcement of foreclosure } \\
\text { or repossession of source assets (column 5), and ongoing } \\
\text { threats to the integrity of transfer of assets to a special } \\
\text { purpose vehicle (SPV) (column 6) are in each case based on } \\
\text { transactional evidence and appraisals of governing laws. }\end{array}$} & \multicolumn{5}{|c|}{$\begin{array}{l}\text { Singapore, for example, in relation to new rules permitting } \\
\text { the creation of real estate investment trusts-although in } \\
\text { each case the probability is small that a completed transaction } \\
\text { would be successfully challenged. }\end{array}$} \\
\hline
\end{tabular}


Figure 4. Thailand: Securitization versus Financial Market Deepening

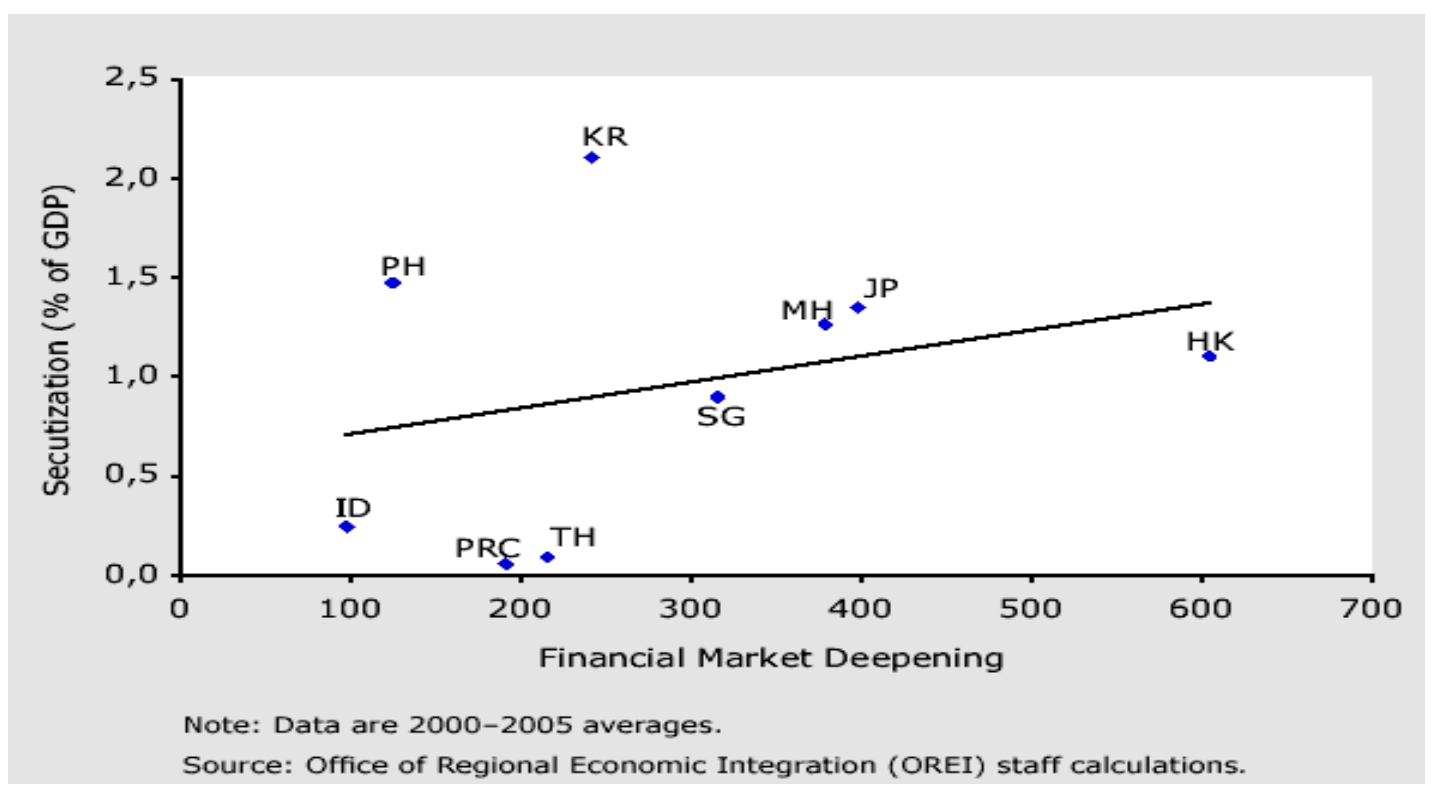

Source: Asian Bond Monitor, April 2007, page 41.

80. To date there have been fourteen securitizations with a total value of B 40 billion. Typically these offerings have been for fixed rate securities with investment grade ratings (although a few issues had multiple tranches with ratings descending from AAA to A).

81. These offerings have been secured by assets with defined cash flows. Legal uncertainties and SEC regulatory review has prevented an issue based upon uncertain future cash flows. Similarly banks originating securitized debt must obtain prior BOT approval.

82. While Thailand has attempted to create a legal regime that facilitates the creation of securitized products, the private sector must also focus on other components of an infrastructure that makes securitization possible. For example, development of a collateralized debt market requires additional infrastructure, such as a credit rating infrastructure that can fully analyze the underlying assets. This requires ready access to information about the underlying transactions and history of repayment so that issuers can create securities with combinations of credit ratings, yield and duration that are attractive to investors. Even comparatively simple transactions require extensive modeling of pool 
performance, relying heavily on robust data records and an understanding of the payment and default history on the pool or similar assets. ${ }^{32}$

\section{Impact of Thai Tax Policies}

83. As noted previously, investments in Thai mutual funds are exempt from capital gains tax. This appears to have been a significant reason for the substantial growth in mutual fund investments. Because of this inherent advantage mutual funds have had less of a need to seek superior investment returns to attract investors. Also, it has adversely affected insurance companies when competing for these funds.

84. One of the key impediments to better functioning capital markets continues to be the SBT, which is a tax on interest earned by financial institutions. This restricts activity and creates distortions in the money markets, asset backed securities markets, etc. It is applied gross, although in practice there is an untested practice of netting out flows, particularly in swaps transactions. For example, market participants typically use the FX forwards market to create a synthetic term money position rather than transacting directly in the term money market. This is solely as a consequence of the SBT.

85. Despite a proposal to reduce the tax to a negligible level of 0.01 percent, it remains at 3 percent. Even if the tax rate is reduced, the administrative cost of compliance will continue to be a problem, even at this small rate.

\section{RECOMMENDATIONS}

86. This note focuses on the primary and secondary fixed income markets in Thailand. While the primary debt market will always be a reflection of the borrowing needs of the government and private sector, the ability of the market to satisfy the diverse borrowing needs of the government and the growing private sector at a reasonable cost will require significant regulatory changes and improvements in infrastructure. The secondary market will grow as the primary market becomes deeper, more orderly and offers a greater variety of instruments.

\footnotetext{
32 "Without adequate or acceptable pool data, the economics of any feasible transaction or program will be problematic. Credit rating practices and transaction modeling depend less upon asset or cash flow quality than on credit enhancement and data history and integrity". Asian Bond Monitor, April 2007, page 59.
} 


\section{A. The Government Debt Market}

- Build more effective benchmarks. There are two broad aspects to this: addressing the flow of new issuance and improving the structure of the stock of existing debt. In terms of new issuance, the PDMO should maximize its issuance potential. For example, it could review the scope to on-lend in B to SOEs, effectively replacing their issuance of guaranteed bonds. While this will not increase the overall size of the public debt market, the authorities could gain a benchmark premium by increasing the size of individual loan bonds. However, such a move would require the PDA to be amended as the current provisions only envisage onlending in foreign currency. At some point, the authorities could jointly review whether there would be scope for the BOT issuance of bonds to be replaced by government bonds, with the consequent funding deposited at BOT on the same terms (i.e., tenor and rate). This would be particularly important if the PDMO wanted to issue short-term loan bonds to achieve particular portfolio objectives. Again, this would require an amendment to the PDA. In terms of restructuring the existing stock, the PDMO could consider a program of buybacks or debt exchanges, consolidating existing bonds into newer benchmarks. This could very quickly establish some key benchmarks. However, the current provisions of the PDA restrict its ability to do this; again an amendment would be required. $^{33}$

- $\quad$ Reduce the frequency of auction. As discussed above, the PDMO offers bonds of similar tenors and duration on average every one or two weeks. This leads to the development of a "broked market" where dealers simply distribute securities to investors at the point of the auction, without taking any inventory risk. Reducing that frequency to about once a month will generate an incentive for investors to access the secondary market in order to match their cashflows, and require a matching need for greater market making from the PDs. In addition, the larger issue size will require a more meaningful underwriting commitment from the PDs with greater risk capital committed to the market. Consequently, changing the auction frequency should be done in conjunction with a review of the PD framework.

- Review the PD framework. To ensure that a change in auction frequency brings the desired outcome of greater activity in the secondary market, the authorities should review the current incentive structure for PDs. This will require clarity about relative

\footnotetext{
${ }^{33}$ The PDA restricts the PDMO's ability to conduct a debt exchange where the price of the existing bond is effectively trading over par. Given that yields have been declining, most older bonds are likely to be trading over par.
} 
priorities - need for underwriting in the primary market; need to provide marketmaking services in secondary market; any objectives to develop the broader fixed income market; etc. - and a range of tools to create appropriate incentives. In general, as the potential incentives are more directly under PDMO control, PDMO should take the lead in designing and overseeing the PD framework. Regardless of framework, PDMO (or BOT) must be ready to effectively monitor and enforce current requirements and need to be ready to strip nonperformers of status.

- Implement proposed amendments to the PDA. As discussed above, the current provisions of the PDA impede the PDMO's ability to discharge its responsibilities in a way that is most beneficial for market development. A number of amendments have already secured Cabinet approval which would address some of the constraints identified. The authorities should do everything in their power to expedite the required Parliamentary process.

\section{B. Recommendations on Corporate Debt Market}

87. Participants in the Thai debt market - issuers, intermediaries, institutions and investors - are still influenced by the events of 1997. Many changes in government policy may be appropriate. But the process of effecting change should be measured, sequenced, orderly and transparent. Most importantly it should be coordinated among all government regulators, both at the policy level and at the implementation level.

\section{A broader pool of issuers and a more diverse mix of products is needed}

88. The Thai debt market must become more diverse. The Thai debt market should not be limited to short and medium term debt issued only by large investment grade public companies. Smaller public companies lacking an investment grade rating and private companies, also lacking a rating, should be permitted to access the debt market.

- $\quad$ The SEC should eliminate its prohibitions / restrictions on mutual fund investments in below investment grade public offerings. Many small or medium sized companies may be sufficiently sound to attract investors but are unable to offer securities because they do not qualify for an investment grade rating. Without an investment grade rating, institutional investors are substantially limited in the ability to invest. The SEC should permit the market to assess the risk and the investment returns of these companies. Professionally managed mutual funds should have the capacity to examine the companies issuing debt and making determinations on whether the higher return warrants any additional risk. 
- SEC limits on the size of a private debt offering should be expanded or eliminated. In most debt markets, private placements are an essential component of the capital formation process. Both public and private companies can issue debt quickly and cheaply to large institutional investors. Large institutional investors have the negotiating leverage to obtain needed financial information from the issuer and the internal analysis capacity to adequately assess the quality of the issue and of the underlying company without the benefit of a securities registration filing.

- $\quad$ The SEC should reexamine the regulations adopted in 2005 for commercial paper offers such as the requirement that the SEC determine if a company is financially solvent before it may issue commercial paper. While a major default invariably produces an examination of the need for greater regulation, a single corporate failure should not result in excessive regulation of short term financings that companies need to conduct business.

89. Re-examine restrictions on foreign borrowers. Thailand should reexamine its restrictions on foreign issuance of baht-denominated debt. In particular, the requirement that foreign issuers obtain MOF approval should be reexamined as well as the requirement that funds raised in baht denominated bonds immediately be converted into foreign currency if the funds are taken offshore. Thailand has a surplus of investment capital that is greater than its domestic needs. It has a growing institutional investor base that is increasingly going offshore to find investments that meet portfolio needs and match liability requirements. While large Asian economies, such as China and India have debt markets that are almost exclusively composed of domestic debt, smaller markets such as Hong Kong SAR, Singapore and New Zealand have actively encouraged the issuance of nonresident corporate debt to enlarge their markets and make them more viable. ${ }^{34}$

- Securitized products could expand the supply of investment grade debt. While there is a limited number of corporations in Thailand that are in a position to issue investment grade debt, and have a need for additional capital, it is possible to increase the supply of investment-grade debt. Innovative intermediaries could securitize other assets to create high quality debt instruments. This approach may have added benefits in that it could address other needs in the Thai financial markets.

a. Currently, the major Thai banks have a substantial general economic downturn risk as over 80 percent of many banks commercial loan portfolios are loans to

\footnotetext{
${ }^{34}$ Gyntelberg, Ma and Remolona, (2006), "Developing Corporate Bond Markets in Asia," Bank for International Settlements Papers No. 26, page 16.
} 
Thai businesses. The risk of a national economic downturn causing degradation of bank loan portfolios could be reduced by transferring portions of a bank loan portfolio to an SPV, which issues collateralized loan obligations based upon a diversified pool of assets. Banks would reduce a portfolio risk, free up capital for new loans and, in the process, create attractive debt securities which the institutional investor community is interested in buying.

b. A similar opportunity exists for collateralized mortgage obligations. In Thailand, few lenders offer long-term fixed rate mortgage products, because of the potential interest rate risk involved for lenders. However, lenders could offer this product without incurring significant duration mismatch if the mortgages were pooled and used to back long-term mortgage backed securities. Such instruments would meet a complementing demand from insurance companies for long duration assets, to match their own liabilities.

c. Because of historical concerns over investment in securities issued by an SPV with no recourse beyond the underlying pool of assets, consideration should also be given to promoting the use of "covered bonds" as an alternative securitization structure. $^{35}$

- $\quad$ Review the use of credit enhancements. Another method to create investment grade products is through the use of credit enhancements. These may be provided in a variety of ways, such as an over-collateralized asset pool, a guarantee to credit risk swap with the originating entity, the use of multiple tranches of securities involving different repayment rights or the purchase of repayment insurance from a third party insurer.

\section{A broader and more diverse investor community is needed}

90. Regulatory changes to expand the number of issuers must be accompanied by parallel changes to provide institutional investors with greater investment flexibility. Just as Thai regulatory policy has tended to limit corporate issuers to large and safe investment grade companies, Thai regulation of institutional investors has restricted investments to these companies. Institutional investors should have greater freedom to make investment choices.

\footnotetext{
35 "Covered bonds share one main objective of cash securitization; to assist in funding by intermediaries. But they are distinct in that they create a security interest for investors. Covered bond holders obtain preferential rights over pools of claims that remain funded assets on the balance sheet of the originating intermediary. Those assets "cover" the new transaction as dedicated collateral, without the irrevocable transfer associated with securitization. Covered bonds (first known in Germany as "pfandbriefe") typically offer a funding cost advantage compared with securitized transactions as the bond holder retains some form of recourse to the originator. As a result, they require less intensive structuring or credit enhancement." Asian Bond Monitor, April 2007, page 35.
} 
a. A major contributor to the lack of corporate debt issued in Thailand is the regulatory restrictions limiting institutions' ability to invest in unrated or below investment grade debt. Because the likely investors are prevented from investing, potential issuers cannot issue. As a result there is an insufficient supply of debt available to meet institutional objectives. This lack of supply is a principal reason for the illiquidity of the secondary market. While the primary goal of a regulator is to protect investors, it is not the only responsibility. Sound regulatory policy should permit institutions to offer investment products that respond to differing investment objectives, and the different risk/reward preferences of investors. Investor protection should not impede the ability of asset managers to make sound investment decisions consistent with the strategies they disclose to their investors.

b. If the SEC introduces greater flexibility into the private placement process, it should provide institutional investors with the ability to resell private offerings to other qualified institutional investors.

\section{Thailand should begin a transition from merit-based regulation of mutual funds} and other collective investment schemes to a disclosure-based system of regulation. Instead of the regulator determining the merits of specific investments and investment strategies (merit based regulation), regulatory policy should be based upon requiring institutional investors such as mutual funds to accurately and fully describe their investment strategies and investment limits, so that investors may choose whether to assume the risks in the hope of superior return (disclosure based regulation). For example, mutual fund operators should be free to create mutual funds that have varying investment and risk strategies. Fund managers should be permitted to utilize their expertise to actively manage a fund to achieve superior returns. They should be permitted to use hedging strategies and engage in repo transactions when appropriate and consistent with the investment objectives they disclose to investors.

The SEC should:

a. Permit the creation of mutual funds that invest primarily or entirely in below investment grade debt.

b. Adopt less restrictive rules on what is an illiquid security.

c. Permit mutual funds to engage in repos as well as reverse repos and to engage in OTC derivatives transactions, if consistent with fund's investment strategy and if practices are clearly and fully disclosed.

d. Provide greater flexibility on risk structure for real estate trusts. Attempts to eliminate risk reduce potential for investment return.

e. Establish a procedure for granting waivers of concentration limits when appropriate and make the process for obtaining waivers/exemptions transparent.

f. Permit funds to invest in private offerings from companies that are unrated. 
g. Permit institutions to invest in offshore offerings without requiring translation of offshore offerings documents.

h. Permit institutions to invest in offshore private offerings.

92. Encourage competition among intermediaries by permitting new entrants. The Thai capital market would benefit from greater competition among intermediaries. The current ceiling on licensed securities brokers and the regulated level of commissions does not promote competition and innovation. This contributes to the lack of active trading of proprietary portfolios by Thai brokers.

a. Debt underwriting is almost entirely by banks, which competes with commercial bank lending. If limits on new broker licenses are eliminated along with fixed commission rates, this will result in increased competition and brokers will have to reexamine the prevailing business model based upon retail commissions. Brokers will have to develop a new business model incorporating a broader range of business activities, such as proprietary trading and competing with banks for debt underwriting.

b. The current corporate debt market is exclusively investment grade debt. There is a limited number of companies able to issue investment grade debt. Intermediaries must develop alternative sources of investment grade rated debt by securitizing quality assets or revenue streams or developing credit enhancement programs. A broader and more diverse group of intermediaries will be more likely to compete by creating new and profitable investment products.

- $\quad$ Re-examine restrictions on investment abroad. As noted above, Thailand currently has a surplus of investment capital. In addition to facilitating the access of foreign borrowers, Thai investors will benefit from investing this capital overseas. Continued regulatory restrictions on Thai intermediaries and constraints on the access of foreign borrowers will limit growth prospects and place Thailand at a competitive disadvantage vis-à-vis alternative markets.

- $\quad$ Facilitate greater expansion of the investor community. Similarly an expansion in the size and diversity of the institutional investor community would be beneficial. Foreign investors, with different investment objectives could improve efficiency and liquidity, benefiting the broader investor community. In fact, foreign banks are more active than Thai banks in proprietary trading which improves secondary market liquidity. In addition to promoting a market with a better balance between buyers and sellers, a deeper market with a wide array of participants is also better able to withstand short term disruption caused by a dramatic influx or exodus of foreign 
investors. ${ }^{36}$ Consequently, the authorities should carefully examine its policies on foreign investment. Capital account restrictions can have unintended consequences, often resulting in an increase in offshore synthetic deals, outside of the control of policy makers.

\section{Other Markets}

- $\quad$ Resolve outstanding technical issues in the private repo market. Given its convening power, the BOT should coordinate an industry working group to resolve the residual technical issues that are impeding the wide adoption of the standard GMRA for the private repo market. Representatives from all key market segments, including the banks, mutual funds, insurance companies and pension companies should all participate. In addition, the SEC, TSD, TBMA, and the insurance regulator should also participate to ensure that regulatory inconsistencies or limitations on institutional participation are resolved.

- Introduce a futures contract. The TFEX should make development of a standard bond derivative and interest rate derivative product its highest priority to enable traders to hedge the interest rate risk created by maintaining an inventory of debt securities.

- $\quad$ Facilitate netting. When these products are created and traded, government regulators should permit banks and securities firms to net outstanding positions for capital adequacy compliance and to cross-settle positions on the listed and OTC markets.

\footnotetext{
36 "Deep markets can absorb large cross-border and cross-asset flows through two-way trading at any maturity point, thus avoiding momentum trading (of the kind recently witnessed in Thailand)." Asian Bond Monitor, April 2007, page 28. "A diversity of investors fosters trading activity. With such diversity, it becomes less likely that different investors will find themselves on the same side of the market, either as sellers or buyers. They are more likely to disagree on the credit quality of an issuer, and thus more willing to trade, and less likely to need liquidity at the same time. In Asia, such diversity seems to be rather limited: the investor base for corporate bonds tends to be dominated by government-controlled provident funds, insurance companies and banks. Once a bond is issued, it normally disappears into the portfolios of buy-and hold investors. Those who might trade more actively, such as fixed income funds and hedge funds, are typically missing from these markets or are not allowed exposures in credit risk... An important class of investor missing from some Asian markets is foreign investors, including global financial intermediaries. In general, myriad market impediments discourage them from participating in the local markets. Among the impediments are withholding taxes and the lack of deep markets for hedging instruments, such as currency swaps. Policymakers in Asia are aware of these deficiencies," Gyntelberg, Ma and Remolona, (2006), page 17.
} 
- $\quad$ Reduce SBT. The authorities should not delay any further in reducing the level of the SBT to the proposed 0.01 percent. In due course, the SBT should be completely eliminated. 


\section{REFERENCES}

Asian Development Bank, 2007, Asian Bond Monitor, (April).

Gyntelbeg, Jacob, Ma, Guomon, and Eli Remolona, 2006, "Developing Corporate Bond Markets in Asia," Bank for International Settlements Papers No. 26.

McCauley, Robert N., and Yung-Chul Park, 2006, "Developing the Bond Market(s) of East

Asia: Global, Regional or National?," Bank for International Settlement Papers No. 30 .

Ruengvirayudh, Pongpen, and Sakkapop Panyanukul, 2006, "The Corporate Bond Market in Thailand," Bank for International Settlement Papers No. 26. 